\title{
A Contribution to the Experimental Microkinetic Approach of Gas/Solid Heterogeneous Catalysis: Measurement of the Individual Heats of Adsorption of Coadsorbed Species by Using the AEIR Method
}

\author{
Daniel Bianchi \\ Institut de Recherches sur la Catalyse et l'Environnement de Lyon, IRCELYON, UMR 5256, \\ Université Claude Bernard-Lyon 1, Bat Chevreul, 43 Bd du 11 Novembre 1918, 69622 Villeurbanne, France; \\ daniel.bianchi@ircelyon.univ-lyon1.fr
}

Received: 28 May 2018; Accepted: 27 June 2018; Published: 29 June 2018

check for updates

\begin{abstract}
The two first surface elementary steps of a gas/solid catalytic reaction are the adsorption/ desorption at least one of the reactants leading to its adsorption equilibrium which can be or not disturbed by the others surface elementary steps leading to the products. The variety of the sites of a conventional catalyst may lead to the formation of different coadsorbed species such as linear, bridged and threefold coordinated species for the adsorption of $\mathrm{CO}$ on supported metal particles. The aim of the present article is to summarize works performed in the last twenty years for the development and applications of an analytical method named Adsorption Equilibrium InfraRed spectroscopy (AEIR) for the measurement of the individual heats of adsorption of coadsorbed species and for the validation of mathematical expressions for their adsorption coefficients and adsorption models. The method uses the evolution of the IR bands characteristic of each of coadsorbed species during the increase in the adsorption temperature in isobaric conditions. The presentation shows that the versatility of AEIR leads to net advantages as compared to others conventional methods particularly in the context of the microkinetic approach of catalytic reactions.
\end{abstract}

Keywords: heats of adsorption; FTIR spectroscopy; AEIR method; Temkin model

\section{Introduction}

One of the aims in gas/solid heterogeneous catalysis is to correlate the global rate of the reaction (defined as the catalytic activity) including in its unit a property of the catalyst (i.e., weight, specific surface area, amount of active sites) to the elementary steps on the surface forming the detailed mechanism of the reaction. This constitutes the microkinetic approach of heterogeneous catalysis [1] which imposes the assessment of the kinetic parameters of the surface elementary steps such as the rate constants: $k$ (pre-exponential factor and activation energy) and adsorption coefficients: $\mathrm{K}$ (pre-exponential factor and heat of adsorption) and the determination of the global rate of the reaction from the detailed mechanism [1]. The kinetic parameters of the surface elementary steps can be obtained either by experimental procedures on model surfaces (surface sciences approach) and conventional powdered catalysts or by theoretical methods (i.e., DFT (Density Functional Theory) calculations). From the detailed mechanism, the global rate of the reaction can be obtained by different either classical [2,3] or more recent [4-6] methods. Using, kinetic parameters from different origins may lead to ambiguities in the conclusions of a microkinetic study considering that they are dependent on the composition, morphology and structure of the catalyst (material gap) which control the type of adsorption sites (terraces, steps and corners for metal supported catalysts) and the interactions between adsorbed species. Similarly, surface sciences studies of catalytic reactions use mainly low 
adsorption pressures (as compared to conventional conditions of heterogeneous catalysis) which may neglect the contribution of weakly adsorbed species (pressure gap). The use of kinetic parameters from different experimental and theoretical approaches is mainly due to the large numbers of surface elementary steps of a detailed mechanism of a catalytic reaction even for bi- and tri-atomic reactants (i.e., $\mathrm{CO} / \mathrm{O}_{2}, \mathrm{CO} / \mathrm{H}_{2}, \mathrm{CO} / \mathrm{NO}, \mathrm{NH}_{3} / \mathrm{NO}$ ). This is due to the fact that the number of either ruptures or creations of bonds in a surface elementary step must be limited. For instance, the number of surface elementary steps in detailed mechanisms of microkinetic studies is: 12 , for $\mathrm{NH}_{3}$ synthesis from $\mathrm{N}_{2} / \mathrm{H}_{2}$ (or its decomposition) on ruthenium catalysts [7-9]; 22, for $\mathrm{NO} / \mathrm{H}_{2}$ on Pt catalysts [10]; 26 , for the production of $\mathrm{C} 1$ and $\mathrm{C} 2$ species from $\mathrm{CO} / \mathrm{H}_{2}$ on cobalt catalysts [11] and 32, for the ethylene oxidation on Ag catalysts [12]. However, among the surface elementary steps of a detailed mechanism, few of them control the global rate of the reaction: they constitute the kinetic model of the reaction [2,3]. This has led our group developing the experimental microkinetic approach (abbreviation EMA) of heterogeneous gas/solid catalytic reactions such as $\mathrm{CO} / \mathrm{O}_{2}[13,14]$ and $\mathrm{CH}_{4}$ production from $\mathrm{CO} / \mathrm{H}_{2}[15,16]$ on $\mathrm{Pt} / \mathrm{Al}_{2} \mathrm{O}_{3}$ catalysts. The main point of the EMA is that considering a plausible kinetic model of a catalytic reaction (based either on literature data or a formal kinetic approach), all the kinetic parameters of interest are obtained by experimental procedures on the conventional dispersed solid catalyst. This prevents using kinetic parameters coming from different sources (surface sciences, conventional catalysts, DFT) and overcomes the impacts of the material and pressure gaps. Note that it is the concurrence between the experimental catalytic activity and that from the EMA which validates the procedure; otherwise the plausible kinetic model must be reconsidered.

The first surface elementary steps of any gas/solid catalytic reaction are the adsorption with a rate $R_{a}$ (rate constant $k_{a}$, activation energy $E_{a}$ equal to 0 for non-activated chemisorption) followed by the desorption with a rate $R_{d}$ (rate constant $k_{d}$, activation energy $E_{d}$ ) of at least one reactant. For $R_{a}-R_{d}=0$, these two elementary steps lead to the adsorption equilibrium of the reactant on the sites which is characterized by the adsorption coefficient $K_{a}=k_{a} / k_{d}$ and a heat of adsorption $\mathrm{E}=\mathrm{E}_{\mathrm{d}}-\mathrm{E}_{\mathrm{a}}\left(\mathrm{K}_{\mathrm{a}}\right.$ determines the coverage of the adsorption sites for adsorption temperature $T_{a}$ and pressure $P_{a}$ ). During a catalytic reaction, the adsorption equilibrium of a reactant can be disturbed or not by others surface elementary steps with a rate $R_{\mathrm{S}}$ and its coverage is controlled by the reaction equilibrium $R_{a}-R_{d}-R_{s}=0[2,3]$. However, in numerous kinetic studies of gas/solid catalytic reactions, it is often assumed that the adsorption equilibrium is not disturbed by the catalytic reaction. It is well known that the adsorption of a reactant may lead to the formation of different adsorbed species. For instance, the reactant $\mathrm{CO}$ of the $\mathrm{CO} / \mathrm{O}_{2}$ and $\mathrm{CO} / \mathrm{H}_{2}$ reactions on supported metal particles may lead to the formation of linear, bridged and threefold coordinated $\mathrm{CO}$ species which are well characterized by their IR bands in distinct wavenumber ranges [17]. Similarly, for the selective catalytic reduction of $\mathrm{NO}$ by $\mathrm{NH}_{3}$ in excess $\mathrm{O}_{2}\left(\mathrm{NH}_{3}\right.$-SCR) on $x \% \mathrm{~V}_{2} \mathrm{O}_{5} / y \% \mathrm{WO}_{3} / \mathrm{TiO}_{2}$ catalysts the adsorption of $\mathrm{NH}_{3}$ leads to $\mathrm{NH}_{3}$ ads-L and $\mathrm{NH}_{4}{ }^{+}$species on the Lewis and Brønsted sites respectively which provide distinct IR bands ([18] and references therein). The role of each coadsorbed species in the reaction is a key point of microkinetic studies. For instance, their respective coverages for a composition of the reactive gas mixture are fixed by their individual heats of adsorption and adsorption coefficients implying that the determination of their values constitutes the first stage of the EMA of the reaction. Moreover, considering that the final aim of a microkinetic study is to express the global rate of the reaction as a function of the kinetic parameters of the surface elementary steps, it is of interest that experimental studies validate mathematical expressions for the adsorption coefficients and the adsorption models for each coadsorbed species formed by the reactants and others compounds of the reactive mixtures (i.e., $\mathrm{H}_{2} \mathrm{O}$ for $\mathrm{NH}_{3}$-SCR to consider the impact of $\mathrm{NH}_{3} / \mathrm{H}_{2} \mathrm{O}$ co-adsorption on the catalytic activity). This is the aim of an original method named Adsorption Equilibrium InfraRed spectroscopy (AEIR) which has been particularly developed in the last twenty years. This method is based on the evolutions of the IR bands characteristic of each adsorbed species during the increase in the adsorption temperature $T_{a}$ in isobaric conditions. The aim of the present article is to summarize the development and the applications of this method. 


\section{Context of the Development of the AEIR Method}

\subsection{Classical Methods for the Measurement of the Heats of Adsorption}

The driving force of this development was the difficulties obtaining the data of interest for a EMA of a catalytic reaction by conventional methods such as the isosteric heats of adsorption of a gas via volumetric/gravimetric measurements, the activation energy of desorption from temperature programmed desorption experiments and the differential/integral heats of adsorption using microcalorimetry. The isosteric heat of adsorption is based on the measurement either in isothermal or isobaric conditions of the coverages of a gas [19]. This allows one determining different couples $\left(T_{a}, P_{a}\right)$ leading to the same coverage which provide the average isosteric heat of adsorption $Q_{i s o}$ at different coverages via the Clausius-Clapeyron equation [19]:

$$
\left(\frac{\partial \ln P_{a}}{\partial\left(\frac{1}{T_{a}}\right)}\right)_{\theta}=\frac{-Q_{i s o}}{R}
$$

where $\mathrm{R}$ is the ideal gas constant. These measurements are tedious to perform and time-consuming, while the method is strongly affected by experimental uncertainties. Moreover the formation of several adsorbed species leads to average values of limited interest in line with the aims of the EMA. Moreover, Equation (1) imposes the use of a large number of experimental data often associated to successive pretreatments of the catalyst which may affect its properties (i.e., sintering of the supported metal particles). Microcalorimetry [20] provides the differential and integral heats of adsorption of a gas according to its coverage. However different experimental difficulties can be encountered such as: the presence of several adsorbed species leading to average values; the impact of gaseous impurities [21]; the non-equilibrium nature of the adsorption at low temperatures [22,23] and the contribution of parallel reactions to the adsorption at high temperatures. Moreover, isosteric methods and microcalorimetry do not provide mathematical expressions for the adsorption coefficient and the adsorption model. The difficulties of these two analytical methods explains the success of temperature programmed desorption (TPD) methods which reveal easy the presence of coadsorbed species having different activation energy of desorption via their rates de desorption $[19,24,25]$. TPD methods consist adsorbing a gas at a temperature low enough to obtain a very low rate of desorption and then increasing the temperature $T_{d}$ in inert atmosphere to desorb progressively the different adsorbed species according to their activation energy of desorption. This leads to a succession of peaks during the increase in $T_{d}$ characterized by the temperature $T_{\mathrm{m}}$ of their maximum $[19,24,25]$. Equations based on classical theories of the adsorption (i.e., the kinetic theory of the gases and the statistical thermodynamics) provide kinetic parameters of interest such as the activation energy of desorption from $T_{m}[19,24,25]$. However, the TPD method imposes a careful design of the experiment in line for instance with the criteria proposed by Gorte et al. [26,27] to prevent the contribution of mass and heat transfers and to neglect the readsorption. These criteria show that readsorption can be rarely prevented using conventional catalysts [28-30]. In these conditions mathematical formalisms may provide the heats of adsorption of the adsorbed species [28-31]. However, similarly to microcalorimetry difficulties in the exploitation of the TPD spectra come from the contribution of parallel surface processes such as surface reconstructions and reactions with impurities (i.e., $\mathrm{O}_{2}, \mathrm{H}_{2} \mathrm{O}$ ). Moreover, for heterogeneous surfaces the TPD peak (without and with readsorption) of an adsorbed species is very broad [31] leading to strongly overlapped peaks for coadsorbed species restricting significantly the access to the kinetic/thermodynamic parameters of interest for an EMA. 


\subsection{Precursor Works Using IR Spectroscopy for the Measurement of the Heats of Adsorption}

Different early works were dedicated to the use of IR spectroscopy in this field. These studies either assumed or established the validity of a linear relationship between (a) the amount of the adsorbed species and (b) the area of its characteristic IR band according to the Beer-Lambert law which is the basis of the quantitative exploitation of FTIR (Fourier-transform infrared spectroscopy) spectra. The first studies were made by surface sciences via Infrared reflection adsorption spectroscopy (IRAS). For instance, Kottle et al. [32] measured the isosteric heats of adsorption of a linear CO species on an evaporated golf film for $T_{a}$ and $P_{a}$ in the ranges of 300-383 K and 7-530 Pa using an IR band in the $2120-2115 \mathrm{~cm}^{-1}$ range according to the coverage. There was a scatter in the data from Equation (1) and the authors provided the average of the heats of adsorption in two coverage ranges: $13.4 \mathrm{~kJ} / \mathrm{mol}$ and $12.4 \mathrm{~kJ} / \mathrm{mol}$ in the coverage ranges $0.1-0.6$ and 0.3-0.6 respectively. Similarly, Richardson et al. [33] measured the isosteric heats of adsorption of a linear CO species (IR band at $2161 \mathrm{~cm}^{-1}$ ) adsorbed on a $\mathrm{NaCl}$ film: $13 \pm 3 \mathrm{~kJ} / \mathrm{mol}$ (via a series of isotherms) after the validation of the Beer-Lambert law. Moreover, after showing that the isotherms were consistent with the Langmuir adsorption model:

$$
\theta\left(T_{a}, P_{a}\right)=\frac{K\left(T_{a}\right) P_{a}}{1+K\left(T_{a}\right) \quad P_{a}}
$$

the values of the adsorption coefficient $K\left(T_{a}\right)$ in the temperature range of the experiments were compared to mathematical expressions from the statistical thermodynamics approach of the adsorption. This allowed the authors obtaining an estimation of the partition function of the adsorbed species. The Goodman's group [34] have used a similar procedure to study the isosteric heats of adsorption of a linear $\mathrm{CO}$ species adsorbed on $\mathrm{Cu}(100)$ characterized by an IR band in the range 2086-2064 $\mathrm{cm}^{-1}$ according to the coverage. They used seven isotherms for adsorption pressures in the range $10^{-3}-130$ Pa showing that the isosteric heat of adsorption varied from $70 \mathrm{~kJ} / \mathrm{mol}$ to $53 \mathrm{~kJ} / \mathrm{mol}$ in the coverage range of $0-0.15 \mathrm{ML}$. The same group has applied the procedure to measure the isosteric heats of adsorption of a linear CO species (IR band in the range of 2096-2053 $\mathrm{cm}^{-1}$ according to the coverage) adsorbed on $\mathrm{Pd}$ film on $\mathrm{Ta}(110)$ using eight isobars in the range of $\approx 10^{-7}-130 \mathrm{~Pa}$ [35]. The authors showed clearly that the isosteric heat of adsorption decreased roughly linearly with the increase in the coverage from $\sim 96 \mathrm{~kJ} / \mathrm{mol}$ to $\sim 40 \mathrm{~kJ} / \mathrm{mol}$ in the coverage range of $0-0.35 \mathrm{ML}$. Similar studies have been performed for the bridged CO species on Pd crystals (IR band in the range 1968-1947 $\mathrm{cm}^{-1}$ ) on $\mathrm{Pd}(100)$ [36]: $121 \pm 8 \mathrm{~kJ} / \mathrm{mol}$ in the coverage range $0.45-0.55 \mathrm{ML}$ and $\operatorname{Pd}(111)[37,38]$ with a linear decrease in the isosteric heat of adsorption from $145 \mathrm{~kJ} / \mathrm{mol}$ to $103 \mathrm{~kJ} / \mathrm{mol}$ in the coverage range of $\approx 0-0.3 \mathrm{ML}$.

In parallel to the studies using IRAS, IR spectroscopy has been applied to the measurement of the heats of adsorption of $\mathrm{CO}$ species on conventional catalysts. These works concerned mainly weakly adsorbed species (heats of adsorption $<\approx 100 \mathrm{~kJ} / \mathrm{mol}$ ) due to the limited performances of the IR cells (working mainly in static conditions) to maintain, the catalyst at high temperatures and pressures on the IR beam. The first works were dedicated to the study of linear CO species adsorbed on the Lewis sites of metal oxides. For instance, Paukshtis et al. [39] studied the individual heats of adsorption of two coadsorbed linear CO species (IR bands in the range of $2150-2230 \mathrm{~cm}^{-1}$ ) on different Lewis acidic sites of 16 dispersed metal oxides such as $\mathrm{MgO}, \mathrm{Al}_{2} \mathrm{O}_{3}, \mathrm{ZrO}_{2}, \mathrm{TiO}_{2}$. Assuming the validity of the Beer-Lambert law for the area (named A) of the IR bands they showed that the different isotherms followed the Langmuir model and using Equation (2) they obtained the heats of adsorption of the different $L$ CO species from the plots $\left[\ln \left(A / A_{0}\right)-1\right]=f(1 / T)$ for each IR bands $\left(\mathrm{A}_{0}\right.$ : the area at saturation of the sites). Thus on $\mathrm{ZrO}_{2}$ they determined that the individual heats of adsorption of two coadsorbed linear CO species characterized by IR bands at 2203 and $2183 \mathrm{~cm}^{-1}$ were of 36 and $28 \mathrm{~kJ} / \mathrm{mol}$ respectively. In a following study [40], the authors have studied the heats of adsorption of a pyridine species on $\mathrm{Al}_{2} \mathrm{O}_{3}$ on $\mathrm{ZrO}_{2}$ characterized by an IR band at $1445 \mathrm{~cm}^{-1}$. However, this adsorbed species did not followed the Langmuir model and the authors provided the 
isosteric heats of adsorption in the range 100-160 kJ/mol by using high temperatures (range 400-700 K) and low adsorption pressures (range $1.3 \times 10^{-2}-3200 \mathrm{~Pa}$ ). Yates et al. [41,42] have performed similar measurements for the $\mathrm{L} \mathrm{CO}$ species adsorbed the Lewis sites of $\mathrm{Al}_{2} \mathrm{O}_{3}$ and $\mathrm{SiO}_{2}$. On $\mathrm{Al}_{2} \mathrm{O}_{3}$ they noted that two species were formed providing strongly overlapped IR bands at $2195 \mathrm{~cm}^{-1}$ (main IR band) and $2213 \mathrm{~cm}^{-1}$. However, using isobaric conditions ( $T_{a}$ in the range of $180-350 \mathrm{~K}$ and $P_{a}=659 \mathrm{~Pa}$ ) they provided via the Langmuir model their average heat of adsorption: $20.9 \mathrm{~kJ} / \mathrm{mol}$. Garrone et al. have studied the linear $\mathrm{CO}$ species on the Lewis sites of different metal oxides: $\mathrm{TiO}_{2}$ [43], $\mathrm{ZrO}_{2}$ [44] and Na-Z5M5 [45] using isothermal conditions at $T_{a} \approx 300 \mathrm{~K}$ for $P_{a}<\approx 13 \mathrm{kPa}$. The point of interest in these studies was that the isotherms on $\mathrm{TiO}_{2}$ and $\mathrm{ZrO}_{2}$ were compared to the Temkin adsorption model to take into account the heterogeneity of the adsorption sites.

Considering the characterization of the kinetic/thermodynamic parameters of adsorbed species with high heats of adsorption relevant of catalytic reactions, the first applications of the IR spectroscopy were dedicated to the measurement of the activation energy of desorption. This was linked to the limited performances of the IR cells using experimental conditions representative of heterogeneous catalytic reactions [46] and reference therein. For instance, Soma-Noto and Sachtler [47] have used this procedure to measure the activation energy of the $\mathrm{L}$ and $\mathrm{B} \mathrm{CO}$ species adsorbed on $\mathrm{Pd} / \mathrm{Al}_{2} \mathrm{O}_{3}$ and $\mathrm{Pd}-\mathrm{Ag} / \mathrm{Al}_{2} \mathrm{O}_{3}$ by studying the evolution of their characteristic IR bands with the duration of the isothermal desorption in vacuum in the range $373-540 \mathrm{~K}: 113 \mathrm{~kJ} / \mathrm{mol}$ and $171 \mathrm{~kJ} / \mathrm{mol}$ respectively. Similarly, some authors have developed TPDIR procedures: this consisted studying the evolution of the intensities of the IR bands of the adsorbed CO species on $\mathrm{Pt} / \mathrm{Al}_{2} \mathrm{O}_{3}$ [48] during the linear increase of the desorption temperature $T_{d}$. This provided the evolution of the coverage $\theta_{X}$ of a adsorbed $X$ species with $T_{d}$ giving the curves $\mathrm{d} \theta_{X} / \mathrm{d} T_{d}$ which were exploited according to classical TPD procedures. This means that the same difficulties than those associated to the TPD procedure may contribute to the experimental data such as the consumption of the adsorbed species by reactions with $\mathrm{H}_{2} \mathrm{O}$ and $\mathrm{O}_{2}$ impurities [49]. The design of microreactor IR cell using gas flow rates at atmospheric pressure and high temperatures on the IR beam has allowed the characterization of the adsorption equilibrium of adsorbed species in experimental conditions representative of heterogeneous catalysis. The difficulties in the design of these IR cells come from the association of a small optical path length (range 2-3 mm) to limit the overlap of the IR spectra of the gaseous and adsorbed species and high temperatures due to the limited thermal stability of the IR windows and their sealing materials [46] and references therein. For instance, using a microreactor IR cell, Bell et al. [50] have determined the heat of adsorption of the linear $\mathrm{CO}$ species on $\mathrm{Ru} / \mathrm{Al}_{2} \mathrm{O}_{3}$ in the coverage range 1-0.85 using $x \% \mathrm{CO} / \mathrm{H}_{2}$ gas mixtures and three isotherms at $\mathrm{T}=498,523$ and $548 \mathrm{~K}$. In this small coverage range, the experimental data were consistent with the Langmuir model (Equation (2)) indicating a heat of adsorption of $106 \mathrm{~kJ} / \mathrm{mol}$. Using a similar IR cell, Kohler et al. [51] have measured the heats of adsorption of linear $\mathrm{CO}$ species on unreduced (IR band at $2132 \mathrm{~cm}^{-1}$ ) and reduced (IR band at $2090 \mathrm{~cm}^{-1}$ ) $x \% \mathrm{Cu} / \mathrm{SiO}_{2}$ solids with $x$ in the range of 2-10. On the unreduced solids three isotherms at 358,378 and $441 \mathrm{~K}$ with $P_{a} \leq 20 \mathrm{kPa}$ showed that the L CO species followed the Langmuir model leading to a heat of adsorption of $25 \mathrm{~kJ} / \mathrm{mol}$. This was confirmed by using the isosteric method showing that the heat of adsorption was independent on the coverage: $\approx 29 \mathrm{~kJ} / \mathrm{mol}$ in the coverage range of $0.1-0.9$. For the reduced solids, isotherms at 358,378 , 441 and $493 \mathrm{~K}$ showed that the coverage of the L CO species was not consistent with the Langmuir model and the isosteric method indicated that the heat of adsorption increased with the decrease in the coverage according to a profile consistent with the Freundlich model with values at low coverages varying with the copper content for $\approx 50 \mathrm{~kJ} / \mathrm{mol}$ to $28 \mathrm{~kJ} / \mathrm{mol}$ for $x=9.5$ to $x=2.1$ [51]. Clarke et al. [52] have confirmed the value at low coverage (range of $0-0.18$ ) for a reduced $7 \% \mathrm{Cu} / \mathrm{SiO}_{2}$ by using as approximation the Langmuir model: $35 \mathrm{~kJ} / \mathrm{mol}$.

The AEIR method has been developed in line with these precursor works using the adsorption of $\mathrm{CO}$ on Pt containing catalysts as case study [26,53-55]. The first step was the design of a microreactor IR cell allowing a significant increase of the highest temperature (until $900 \mathrm{~K}$ ) as compared to literature data [46] (this improvement was imposed by the high heats of adsorption at low coverages of the 
L CO species on Pt particles). The aim of the experimental procedure of the AEIR method was to combine measurements at the adsorption equilibrium (i.e., this prevents the impacts of heat and mass transfers) and temperature programmed procedures (rapidity of the experiment). Considering our interests for the EMA of gas/solid catalytic reactions, the aims of the exploitation of the IR spectra were the measurement of the individual heats of adsorption of coadsorbed species via the validation of mathematical expressions for the adsorption coefficients and adsorption models provided by classical theories of the adsorption. Two applications of the AEIR method are used to support the presentation: the adsorptions of $\mathrm{CO}$ on $\mathrm{Pt} / \mathrm{Al}_{2} \mathrm{O}_{3}$ and $\mathrm{NH}_{3}$ on $\mathrm{TiO}_{2}$ based catalysts considered as the first steps of the EMA of catalytic reactions such $\mathrm{CO} / \mathrm{H}_{2}$ and de- $\mathrm{NO}_{x}$ from $\mathrm{NH}_{3}-\mathrm{SCR}$ respectively.

\section{The Adsorption Equilibrium InfraRed Spectroscopy Method}

\subsection{IR Cell Microreactor for the Application of the AEIR Method}

The AEIR method has been developed using a homemade stainless steel microreactor IR cell in transmission mode working at atmospheric pressure [46]. It has been designed (see Figure 1 in [46]) taking into account previous models and literature data. Briefly, a short path length $(\approx 2.2 \mathrm{~mm})$ limits the contribution of the gas phase to the IR spectra of the adsorbed species allowing using adsorption pressure of $\mathrm{CO}$ until $\approx 20 \mathrm{kPa}$. The originality of the IR cell is that the two $\mathrm{CaF}_{2} \mathrm{IR}$ windows delimiting the path length in the heating part of the cell, are positioned on polished flat flanges without sealing materials (the two windows was maintained by using vacuum on one of their faces). This permits using temperatures in the range of $300-900 \mathrm{~K}$ with an heating rate of $\approx 0.1-20 \mathrm{~K} / \mathrm{min}$ [46]. The powdered catalyst (weight in the $40-200 \mathrm{mg}$ range) was compressed into a disk (diameter $=18 \mathrm{~mm}$ ) positioned on the IR beam between the two $\mathrm{CaF}_{2}$ windows. In a recent work, it has been shown that a DRIFT cell can be used for the AEIR method (using the pseudo absorbance mode) taking into account that according to its design, heat transfers may create some difficulties to know the exact temperature of the fraction of the solid submitted to the IR beam for $\mathrm{T}>\approx 623 \mathrm{~K}[56]$.

\subsection{Experimental Procedure of the AEIR Method}

After pretreatment of the catalyst at high temperatures (i.e., $\mathrm{H}_{2}$ reduction at $713 \mathrm{~K}$ for $2.9 \%$ $\mathrm{Pt} / \mathrm{Al}_{2} \mathrm{O}_{3}$ and $\mathrm{O}_{2}$ oxidation for $\mathrm{TiO}_{2}$ based solids) it is cooled to $300 \mathrm{~K}$. Then the switches $\mathrm{H}_{2}\left(\right.$ or $\left.\mathrm{O}_{2}\right)$ $\rightarrow \mathrm{He} \rightarrow x \% \mathrm{G} / \mathrm{He}$ (i.e., $\mathrm{G}$ either $\mathrm{CO}$ or $\mathrm{NH}_{3}$ ) lead to the adsorption of $\mathrm{G}$ at the adsorption pressure $P_{a}=x 10^{3} \mathrm{~Pa}$. After the stabilization of the IR bands of the adsorbed species, indicating the attainment of the adsorption equilibrium, the adsorption temperature $T_{a}$ is increased $(\alpha \approx 10 \mathrm{~K} / \mathrm{min})$ in the presence of $x \% \mathrm{G} / \mathrm{He}$ following the changes in the IR spectra of the adsorbed species. This provides the change in the intensities (in absorbance mode) of the IR bands characteristic of each adsorbed species $X_{\text {ads }}$ at the adsorption equilibrium as a function of $T_{a}$ in isobaric condition. It has been shown that the gas/solid system evolves by a succession of adsorption equilibriums taking into account that the high adsorption pressure and the moderate heating rate lead to a fast change from an adsorption equilibrium at $\left(T_{a}, P_{a}\right)$ to that at $\left(T_{a}+\mathrm{d} T_{a}, P_{a}\right)$ [30]. Similarly to the classical methods dedicated to the measurement of the heats of adsorption, surface processes parallel to the adsorption (i.e., surface reconstruction, $\mathrm{CO}$ dissociation) may contribute to the change of the intensity of the IR bands of the adsorbed species. However, the AEIR method permits to take into account these contributions by comparing the intensities of the IR bands at different adsorption temperatures during the first heating (i.e., $713 \mathrm{~K}$ ) and cooling (i.e., $300 \mathrm{~K}$ ) cycle in $x \% \mathrm{G} / \mathrm{He}$. Often differences are observed due to reconstruction [53-55] and $\mathrm{CO}$ dissociation [57]. However, these processes are ended after the first heating/ cooling cycle in $x \% \mathrm{G} / \mathrm{He}$ as attested by the repeatability of the intensities of the IR bands of the adsorbed species during a second heating/cooling cycle in $x \% \mathrm{G} / \mathrm{He}$ : this means only the IR spectra of the second cycle (stabilized surface) are exploited via the AEIR method. The intensities of the IR bands of the adsorbed species can be modified by another process as observed for the adsorption of $\mathrm{CO}$ on supported $\mathrm{Ag}^{\circ}$ particles [58]. After a first heating/cooling cycle, it has been observed that 
the IR band of the B CO species (at $1994 \mathrm{~cm}^{-1}$ ) increases during the heating stages in parallel to the decrease in the IR band of the L CO species $\left(\right.$ at $2044 \mathrm{~cm}^{-1}$ ). The reverse situation is observed during the cooling stages [58]. A similar process has been described by Müslehiddinoglu and Vannice [59] during the isothermal desorption at $300 \mathrm{~K}$ of the adsorbed $\mathrm{CO}$ species on $\mathrm{Ag}^{\circ}$ particles. According to literature data [58] and references therein, this has been ascribed to an intensity transfer (in the $1 / 1$ ratio) from the IR band of the B CO species to that of the L CO species. This transfer does not contribute significantly to the observations for different situations either if the amount of $\mathrm{B} C \mathrm{CO}$ species is low as compared to that of the $\mathrm{L} \mathrm{CO}$ species (i.e., $\mathrm{Pt} / \mathrm{Al}_{2} \mathrm{O}_{3}$ ) or if the two adsorbed species have different heats of adsorption allowing the significant decrease in the coverage of one of them without affecting that of the second species. For others situations the AEIR method does not apply.

As example of experimental data of the AEIR method, the inset of Figure 1 shows that the adsorption of $1 \% \mathrm{CO} / \mathrm{He}$ at $300 \mathrm{~K}$ on $2.9 \% \mathrm{Pt} / \mathrm{Al}_{2} \mathrm{O}_{3}$ leads to an IR spectrum with three IR bands at 2073, 1878 and $1835 \mathrm{~cm}^{-1}$ ascribed [53-55] to linear, bridged and three fold coordinated CO species (named L, B and 3FC CO species respectively). Figure 1 gives the evolution of the IR band of the L CO species during the second increase in $T_{a}$ for $1 \% \mathrm{CO} / \mathrm{He}$. Similar spectra are obtained for the $\mathrm{B}$ and $3 \mathrm{FC}$ CO species.

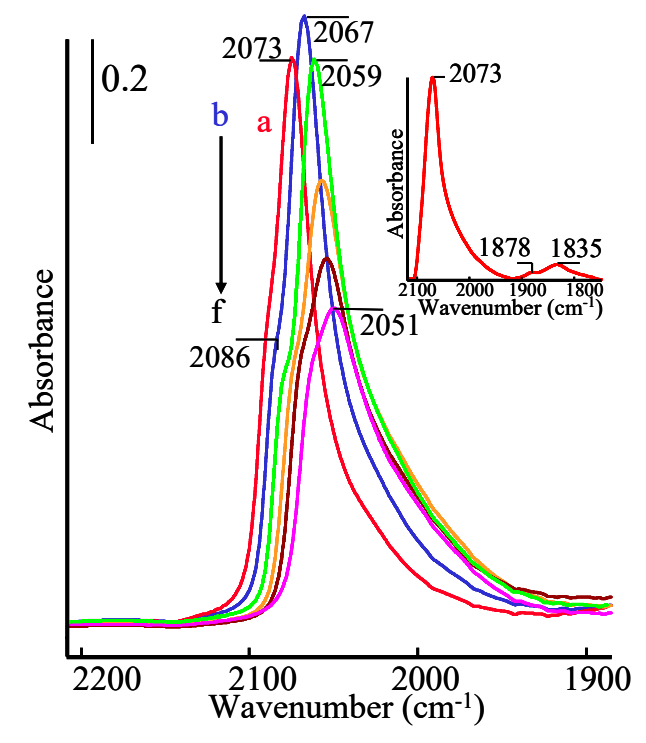

Figure 1. Evolution of the IR band of the linear $\mathrm{CO}$ species adsorbed on a reduced $2.9 \% \mathrm{Pt} / \mathrm{Al}_{2} \mathrm{O}_{3}$ catalyst with the adsorption temperature $T_{a}$ at $P_{a}=1 \mathrm{kPa}$. (a-f) $T_{a}=378,453,533,633,693$ and $783 \mathrm{~K}$. Insert: $\mathrm{IR}$ bands of the different adsorbed $\mathrm{CO}$ species on $2.9 \% \mathrm{Pt} / \mathrm{Al}_{2} \mathrm{O}_{3}$ for $T_{a}=300 \mathrm{~K}$ and $P_{a}=1 \mathrm{kPa}$.

\subsection{Exploitation of the IR Spectra According to the AEIR Method}

Considering the Beer-Lambert law, the amount of each adsorbed species $\mathrm{X}$ is proportional to the intensity of its IR band. This allows one obtaining the experimental evolutions of the coverage of each adsorbed species: $\theta \mathrm{X}_{\mathrm{ex}}$, with $\mathrm{T}_{\mathrm{a}}$, in isobaric conditions from the change in its IR band as for the $\mathrm{L} C O$ species in Figure 1:

$$
\theta X_{e x}=\frac{A_{X}\left(T_{a}\right)}{A_{X M}}
$$

where $A_{X}\left(T_{a}\right)$ and $A_{X M}$ are the area of the IR band (in absorbance mode with values lower than $\approx 1.1$ ) characteristic of the $X$ species at $T_{a}$ and at saturation of the sites respectively. The value of $A_{X M}$ is obtained by ascertaining that the area of the IR band is not modified by either the increase in $T_{a}$ in isobaric conditions or the increase in $P_{a}$ in isothermal conditions. This is often the situation for the adsorbed CO species on metal particles at $T_{a}=300 \mathrm{~K}$ for $P_{a}$ in the range 1-10 $\mathrm{kPa}$ due to their high heats of adsorption at full coverage. However, for weakly adsorbed species such as the linear CO 
species on the Lewis sites of metal oxides: $\mathrm{ZrO}_{2}[60]$ and $\mathrm{TiO}_{2}$ [61] the saturation of the adsorption sites is not obtained at $300 \mathrm{~K}$ for the highest adsorption pressure available with the IR cell. For this situation, an estimation of $\mathrm{A}_{X \mathrm{M}}$ is obtained according to the procedure of Kohler et al. [51]: assuming that the adsorption follows the Langmuir's model (Equation (2)) for non dissociative chemisorption, then the plot of $\left(1 / \mathrm{A}_{\mathrm{X}}(300 \mathrm{~K})\right)$ vs. $\left(1 / \mathrm{P}_{\mathrm{a}}\right)$ provides $\mathrm{A}_{\mathrm{XM}}$. For a gas/solid system leading mainly to one adsorbed species, the validity of Equation (3) has been ascertained by different authors $[33,35,36,39,50,51]$ and we have confirmed this point for the $\mathrm{L} \mathrm{CO}$ species on the reduced metal particles of $\mathrm{Cu} / \mathrm{Al}_{2} \mathrm{O}_{3}[62,63]$ and $\mathrm{Ir} / \mathrm{Al}_{2} \mathrm{O}_{3}$ [64]. If the adsorption leads to different adsorbed species such as $\mathrm{L}, \mathrm{B}$ and $3 \mathrm{FC} \mathrm{CO}$ species on $\mathrm{Pt} / \mathrm{Al}_{2} \mathrm{O}_{3}$ (inset Figure 1), the ascertainment of the Beer-Lambert law presents difficulties, due to the fact that at $300 \mathrm{~K}$, volumetric/gravimetric methods provide the total amount of adsorbed species: $\mathrm{Q}_{\mathrm{T}}=\Sigma \mathrm{Q}_{\mathrm{X}}$ whereas $\mathrm{A}_{\mathrm{X}}$ depends of a specific $\mathrm{X}$ species. For the adsorption of $\mathrm{CO}$ on $\mathrm{Pt}$ particles, FTIR spectroscopy shows that for $1 \% \mathrm{CO} / \mathrm{He}$ and $T_{a}>550 \mathrm{~K}$, mainly the L CO species is present on the surface due to the difference in the heats of adsorption of the $\mathrm{L}, \mathrm{B}$ and $3 \mathrm{FC}$ CO species. In these conditions, the validity of Equation (3) has been ascertained performing carbon mass balance with a mass spectrometer at the introduction of $1 \% \mathrm{CO} / \mathrm{He}$ taking into account that $\mathrm{CO}$ is involved in different processes: adsorption; dissociation and reaction with $\mathrm{OH}$ groups of the support forming $\mathrm{CO}_{2}$ and $\mathrm{H}_{2}$ [65]. These results and literature data have led us applying the Beer-Lambert law for all adsorbed species $X_{\text {ads }}$ providing from Equation (3) the experimental curve $\theta X_{e x}=f\left(T_{a}\right)$ at different adsorption pressures $P_{a}$. For instance, symbols $\mathbf{i n}$ Figure 2 provide the evolution of the coverage of the linear $\mathrm{CO}$ species $\theta \mathrm{L}_{\mathrm{ex}}$ on the reduced $2.9 \% \mathrm{Pt} / \mathrm{Al}_{2} \mathrm{O}_{3}$ catalyst for $P_{a}=1 \mathrm{kPa}$ considering the data in Figure 1. Similarly, symbols $\boldsymbol{\Delta}$ and give the experimental coverage of the B and 3FC CO species (inset Figure 1) for $P_{a}=1 \mathrm{kPa}$ from experiments similar to Figure 1 with a higher amount of catalyst to improve the accuracy of the measurements and after the decomposition of their overlapped IR bands [54]. Note that for the B CO species, $A_{M}$ in Equation (3) is obtained at $300 \mathrm{~K}$ for $P_{a} \geq 10 \mathrm{kPa}$ [34]. The experimental data in Figure 2 are compared to theoretical curves providing the individual heats of adsorption and the mathematical expressions of interest for the adsorption equilibriums of $\mathrm{L}, \mathrm{B}$ and 3FC CO species.

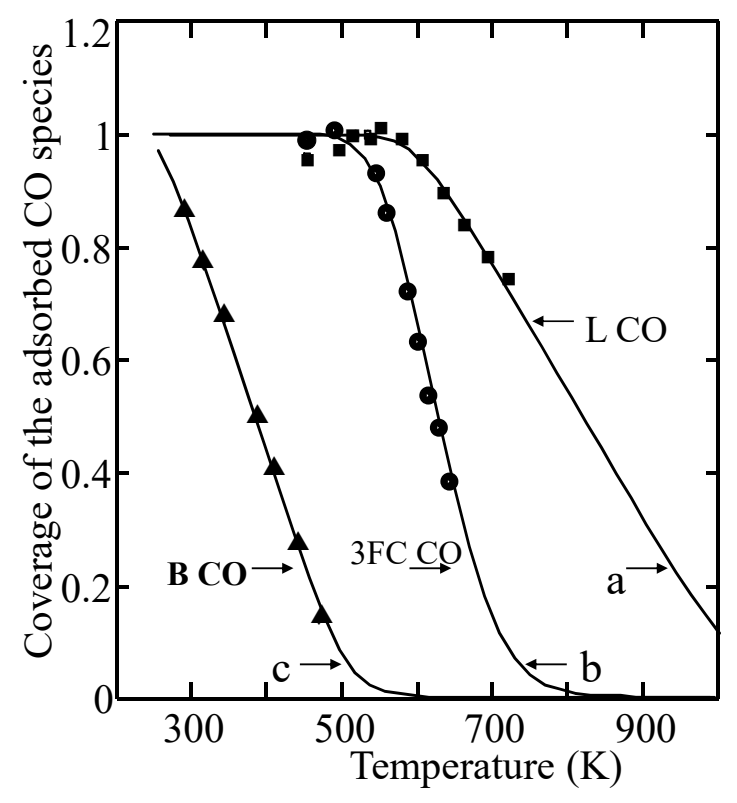

Figure 2. Comparison between experimental and theoretical curves $\theta_{X}=f\left(T_{a}\right)$ at $P_{a}=1 \mathrm{kPa}$ for the different $\mathrm{XCO}$ species on $2 \% \mathrm{Pt} / \mathrm{Al}_{2} \mathrm{O}_{3}: \mathbf{\square}, \bullet$, and $\boldsymbol{\Lambda}$ experimental data for the $\mathrm{L}, 3 \mathrm{FC}$ and $\mathrm{B} \mathrm{CO}$ species respectively; (a), (b) and (c) theoretical curve according to Equations (4) and (5) for the L, 3FC and B $\mathrm{CO}$ species (see the text for the $\mathrm{E}_{0}$ and $\mathrm{E}_{1}$ values of each adsorbed species). 


\subsection{Exploitation of the Experimental Curves $\theta X_{e x}=f\left(T_{a}, P_{a}\right)$ According to the AEIR Method}

Considering our interest for the development of the EMA of catalytic reactions, the aims of the exploitation of the experimental data were the measurement of the individual heats of adsorption of the coadsorbed species via the validation of mathematical expressions for the adsorption coefficients and adsorption models provided by the classical theories of adsorption. It is a fact that the Langmuir model (Equation (2)) is rarely representative of experimental data for strongly adsorbed species on conventional catalysts due to the heterogeneity of the adsorption sites/adsorbed species. However, its extension to heterogeneous surfaces, via the integral approach and the distribution functions $[15,16]$ and referenced therein, provides different equations for others adsorption models. For instance assuming a linear decrease in the heat of adsorption of an adsorbed species with the increase in its coverage, the integral approach leads to the generalized Temkin equation model [66] for non dissociative adsorption:

$$
\theta_{t h}=\frac{\mathrm{RT}_{\mathrm{a}}}{\Delta \mathrm{E}} \times \ln \left(\frac{1+K\left(\mathrm{E}_{0}\right) \quad \mathrm{P}_{\mathrm{a}}}{1+K\left(\mathrm{E}_{1}\right) \quad \mathrm{P}_{\mathrm{a}}}\right)
$$

where $\mathrm{E}_{0}\left(\mathrm{~K}\left(\mathrm{E}_{0}\right)\right)$ and $\mathrm{E}_{1}\left(\mathrm{~K}\left(\mathrm{E}_{1}\right)\right)$ are the heats of adsorption (adsorption coefficient) at low and high coverages and $\Delta \mathrm{E}=\mathrm{E}_{0}-\mathrm{E}_{1}$. The statistical thermodynamics and the absolute rate theory provide the adsorption coefficient as a function of the partition functions of the gaseous molecule, the adsorbing site and adsorbed molecule [19,67-69]. In the temperature range of gas/solid catalytic reactions $\approx 300-900 \mathrm{~K}$, the partition function of a gaseous molecule is dominated by those of translation, rotation and vibration whereas that of the localized adsorbed molecule is dominated by those of rotation and vibration. In many cases, the ratio of the partition functions of rotation and vibration of the gaseous and adsorbed species can be reasonably approximated to $\approx 1[30,70]$ leading to the mathematical expression of the adsorption coefficient:

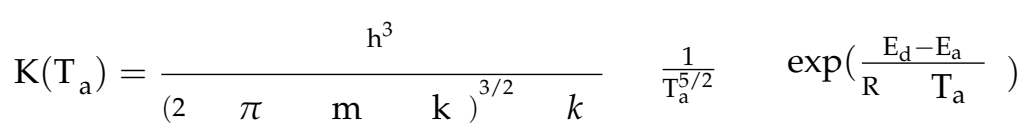

where $\mathrm{h}$ is Planck's constant, $\mathrm{k}$ is Bolztmann's constant, $\mathrm{m}$ is the mass of the molecule, $\mathrm{E}_{\mathrm{d}}$ and $\mathrm{E}_{\mathrm{a}}$ are the activation energies of desorption and adsorption respectively, while $E=E_{d}-E_{a}$ is the heat of adsorption. Note that as commented by Tompkin [19], the attainment of the adsorption equilibrium implicates a surface diffusion of the adsorbed species: this is compatible with a localized adsorbed species considering that localized means that the lifetime of the adsorbed species at the site is longer than its time in flight on the surface.

To obtain the individual heats of adsorption of coadsorbed species, the experimental evolutions of the coverage of each species (Figure 2) are compared to theoretical curves obtained by using Equations (4) and (5) and selecting a couple of $E_{0}$ and $E_{1}$ values leading to an overlap between experimental and theoretical curves (note that for $\mathrm{E}_{0} \approx \mathrm{E}_{1}$ the theoretical curve obtained from Equation (4) is overlapped with that from the Langmuir model (Equation (2)). For instance in Figure 2, the curves a, b, c which overlap the experimental data for the L, B and 3FC CO species are obtained considering the following couples of heats of adsorption $\left(\mathrm{E}_{0}, \mathrm{E}_{1}\right)$ in $\mathrm{kJ} / \mathrm{mol}$ at low and high coverages: $(206,115),(94,45)$ and $(135,104)$. This shows that the AEIR method allows one determining the heats of adsorption of an adsorbed species from a single isobar. The practice shows that the choice of the $\mathrm{E}_{1}$ and $\mathrm{E}_{0}$ values is limited to short ranges $(\approx \pm 5 \mathrm{~kJ} / \mathrm{mol})$ otherwise the experimental and theoretical curves are clearly distinct. This accuracy is due to the fact that $\mathrm{E}_{1}$ and $\mathrm{E}_{0}$ determine the temperature leading to the decrease in the coverage from 1 and the slope of the linear section of the isobar respectively [53].

\subsection{Heats of Adsorption from the AEIR Method and Isosteric Heats of Adsorption}

Using three isobars similar to Figure 1 for $P_{C O}=1000,100$ and $10 \mathrm{~Pa}$ [53], the validity of the AEIR procedure has been ascertained for the $\mathrm{L} C \mathrm{C}$ species by showing that the $\mathrm{E}_{\theta}$ values obtained 
from Equations (4) and (5) are consistent with the isosteric heats of adsorption (Equation (2)) which is independent on the adsorption model. Similar conclusions have been obtained for different adsorbed CO species on metal particles [54,62,64]. This indicates that Equations (4) and (5) provide a very well representation of the properties of adsorbed CO species whereas as compared to the isosteric heats of adsorption a single isobar is needed using the AEIR method to obtain the individual heats of adsorption of coadsorbed species.

It is a fact that the same adsorption model (localized adsorbed species and Temkin's model) allows fitting numerous experimental data dedicated to the heats of adsorption of $\mathrm{L}$ and $\mathrm{B} \mathrm{CO}$ species formed by the adsorption of $\mathrm{CO}$ on supported metal particles on metal oxides as indicated in Table 1.

Table 1. Heats of adsorption at low $\left(\mathrm{E}_{0}\right)$ and high $\left(\mathrm{E}_{1}\right)$ coverages of the Linear and Bridged CO species adsorbed on different metal supported particles on metal oxides by using the AEIR method.

\begin{tabular}{cccccc}
\hline & \multicolumn{5}{c}{ Heat of Adsorption of Adsorbed CO Species in $\mathbf{~ k J / m o l}$} \\
\cline { 2 - 5 } Metal Particles on Alumina & \multicolumn{2}{c}{ Linear CO Species } & Bridged CO Species & \multirow{2}{*}{ Ref. } \\
\cline { 2 - 5 } & $\mathbf{E}_{\mathbf{1}}$ & $\mathbf{E}_{\mathbf{0}}$ & $\mathbf{E}_{\mathbf{1}}$ & $\mathbf{E}_{\mathbf{0}}$ & \\
\hline $\mathrm{Pt}^{\circ}$ & 115 & 206 & 45 & 94 & {$[53-55]$} \\
$\mathrm{Pd}^{\circ}$ & 54 & 92 & 92 & 168 & {$[71]$} \\
$\mathrm{Rh}^{\circ}$ & 103 & 195 & 75 & 125 & {$[72]$} \\
$\mathrm{Ir}^{\circ}$ & 115 & 225 & & & {$[64]$} \\
$\mathrm{Ru}^{\circ}$ & 115 & 175 & & & {$[73]$} \\
$\mathrm{Cu}^{\circ}$ & 57 & 82 & 78 & 125 & {$[62]$} \\
$\mathrm{Au}^{\circ}$ & 47 & 74 & & & {$[61]$} \\
$\mathrm{Ag}^{\circ}$ & 58 & 76 & 84 & 88 & {$[58]$} \\
$\mathrm{Ni}^{\circ}$ & 100 & 153 & 106 & 147 & {$[74]$} \\
$\mathrm{Fe}^{\circ}$ & 79 & 105 & & & {$[75]$} \\
$\mathrm{Co}^{\circ}-\mathrm{C}^{*}$ & 93 & 165 & & & {$[57]$} \\
\hline
\end{tabular}

${ }^{*} \mathrm{Co}^{\circ}$ sites modified by $\mathrm{C}$ deposition from the $\mathrm{CO}$ dissociation.

The versatility of the Temkin model is probably due to the fact that it is the best representation of the heterogeneity of the surface for strongly adsorbed species on conventional catalysts. Classically the heterogeneity for adsorbed species is ascribed to either a difference in the adsorption properties of the sites (biographical or intrinsic heterogeneity) or an interaction between adsorbed species (induced heterogeneity) [66]. The Temkin model is one of the proposals [76,77] to represent by a equation the evolution of the coverage of a gas on a heterogeneous surface as a function of the adsorption temperature and pressure. Different studies have considered the contribution of each type of heterogeneity on the modeling of the coverage in particular the induced heterogeneity due to lateral interaction (Ref. [78] and references therein). However, Temkin [66] noted that the two types of heterogeneities can be simultaneously operant and that a single equation must be representative of this situation to prevent an excessive mathematical complexity. This has been justified by different authors [79-81]. Moreover, considering that the heats of adsorption of an adsorbed species at low $\left(\mathrm{E}_{0}\right)$ and high $\left(\mathrm{E}_{1}\right)$ coverages have limited values such as $206 \mathrm{~kJ} / \mathrm{mol}$ and $115 \mathrm{~kJ} / \mathrm{mol}$ for the L CO species on Pt particles (Table 1), the comparison of a linear (Temkin model) and an exponential (Freundlich model) decrease in the heats of adsorption with the increase in the coverage according to $\mathrm{E}_{\mathrm{T}}(\theta)=\left[\mathrm{E}_{0}-\left(\mathrm{E}_{0}-\mathrm{E}_{1}\right) \theta\right]$ and $\mathrm{E}_{\mathrm{F}}(\theta)=\mathrm{E}_{0} \exp \left[-\theta \ln \left(\mathrm{E}_{0} / \mathrm{E}_{1}\right)\right]$ respectively, shows that the highest difference $(6.6 \mathrm{~kJ} / \mathrm{mol}$ at coverage 0.5$)$ is in the range of the accuracy of the measurements.

\subsection{Development of the AEIR Method}

The AEIR method has been applied to different gas/catalyst systems such as: NO on $2.7 \%$ $\mathrm{Pt} / \mathrm{Al}_{2} \mathrm{O}_{3}$ [82]; aromatic hydrocarbons on $\mathrm{SiO}_{2}[70]$ and $\mathrm{NH}_{3}[18,83,84]$ and $\mathrm{H}_{2} \mathrm{O}$ [85] on different $\mathrm{TiO}_{2}$ based solids. For this last application it has been observed that some IR bands provide $\theta_{e x}=f\left(T_{a}\right)$ 
curves which are not consistent with Equations (4) and (5). This is ascribed to the fact that the IR band selected for the measurement is due to the contributions of two adsorbed species having different heats of adsorption. In this situation $\theta_{\mathrm{ex}}=\mathrm{f}\left(T_{a}\right)$ gives the evolution of the average coverage of the two adsorbed species. A development of the AEIR method allows one obtaining the individual heats of adsorption of the two species as shown for the adsorption of $\mathrm{NH}_{3}$ on the Lewis sites (named $\mathrm{NH}_{3 a d s-\mathrm{L}}$ species) of $\mathrm{TiO}_{2} \mathrm{P} 25$ from Degussa [18] which is of particular interest because different IR bands can be used for the measurement of the individual heats of adsorption of the coadsorbed $\mathrm{NH}_{3 a d s-\mathrm{L}}$ species supporting the development of the method. For instance, Figure 3 gives the evolution of the IR bands in the range $2000-1100 \mathrm{~cm}^{-1}$ of the $\mathrm{NH}_{3}$ species adsorbed on $\mathrm{TiO}_{2}$ with the increase in $T_{a}$ for $0.1 \%$ $\mathrm{NH}_{3} / \mathrm{He}$.

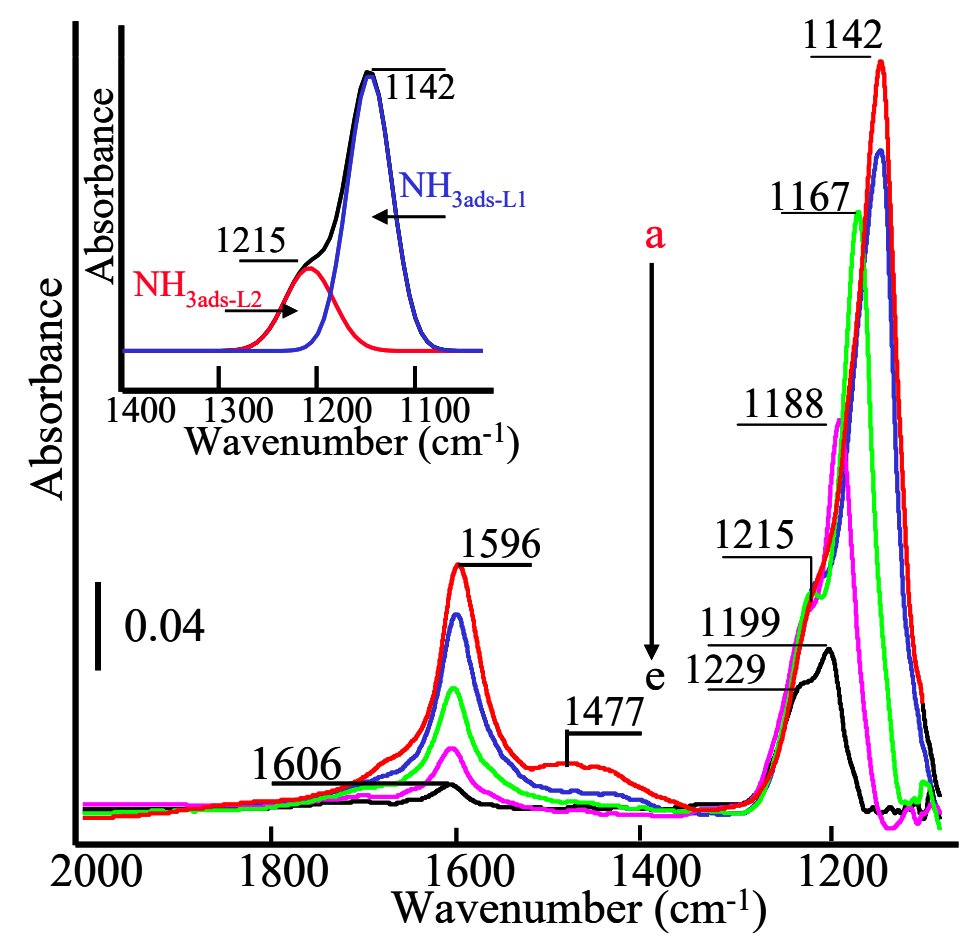

Figure 3. Impact of the adsorption temperature $T_{a}$ on the IR bands of the adsorbed $\mathrm{NH}_{3}$ species on $\mathrm{TiO}_{2}-\mathrm{P} 25$ using $0.1 \% \mathrm{NH}_{3} / \mathrm{He}$ : (a-e) $T_{a}=300,373,473,573$ and $673 \mathrm{~K}$. Inset: Decomposition of the $\delta_{\mathrm{s}}$ IR bands of the $\mathrm{NH}_{3 a d s-L 2}$ and $\mathrm{NH}_{3 \text { ads-L1 }}$ species at $300 \mathrm{~K}$.

At $300 \mathrm{~K}$, the overlapped IR bands at 1142 and $1215 \mathrm{~cm}^{-1}$ in Figure 3 are ascribed to the $\delta_{\mathrm{s}}$ deformations of two adsorbed $\mathrm{NH}_{3}$ species on different Lewis sites $\mathrm{L} 1$ and $\mathrm{L} 2$ named $\mathrm{NH}_{3 a d s-L 1}$ and $\mathrm{NH}_{3 a d s-L 2}$ respectively [18] whereas their $\delta_{\text {as }}$ deformations contribute to the IR band at $1596 \mathrm{~cm}^{-1}$. Moreover, in Figure 3, the broad IR band at $1477 \mathrm{~cm}^{-1}$ and the shoulder at $1680 \mathrm{~cm}^{-1}$ are ascribed to the antisymmetric and symmetric deformation of $\mathrm{NH}_{4}{ }^{+}$species formed by the adsorption of $\mathrm{NH}_{3}$ on Brønsted sites [18] and references therein. The increase in $T_{a}$ to $713 \mathrm{~K}$ for $0.1 \% \mathrm{NH}_{3} / \mathrm{He}$ leads to the decrease in the different IR bands: those of the $\mathrm{NH}_{4}{ }^{+}$species disappear at $\approx 423 \mathrm{~K}$ indicating weakly adsorbed species whereas those of the $\mathrm{NH}_{3 \text { ads-L }}$ species are present at $713 \mathrm{~K}$. The individuals heats of adsorption of the $\mathrm{NH}_{3 \text { ads-L1 }}$ and $\mathrm{NH}_{3 a d s-L 2}$ species have been obtained after decomposition of the two $\delta_{\mathrm{S}}$ IR bands as shown in the inset of Figure 3 for $\mathrm{T}=300 \mathrm{~K}$. Considering similar IR absorption coefficients for the two $\mathrm{NH}_{3 a d s-\mathrm{L}}$ species and taking into account that they are at full coverage at $300 \mathrm{~K}$ for $0.1 \% \mathrm{NH}_{3} / \mathrm{He}$, the decomposition indicates that the $\mathrm{L} 1$ and $\mathrm{L} 2$ sites represent $70 \%$ and $30 \%$ of the Lewis sites of $\mathrm{TiO}_{2} \mathrm{P} 25$ respectively.

After decomposition at each adsorption temperature, the square and triangle symbols in Figure 4 give from Equation (3), the $\theta_{\mathrm{ex}}=\mathrm{f}\left(\mathrm{T}_{a}\right)$ curves in isobaric conditions of $\mathrm{NH}_{3 a d s-\mathrm{L} 1}$ and $\mathrm{NH}_{3 \text { ads-L2 }}$ respectively. 
Curves $a$ and $b$ which overlap the experimental data are obtained using Equations (4) and (5) with the following couples of $\left(\mathrm{E}_{0}\right.$ and $\left.\mathrm{E}_{1}\right)$ values in $\mathrm{kJ} / \mathrm{mol}(112,56)$ and $(160,104)$ for the $\mathrm{NH}_{3 \text { ads-L1 }}$ and $\mathrm{NH}_{3 \text { ads-L2 }}$ species respectively. The circle symbols in Figure 4 give $\theta_{\mathrm{ex}}=\mathrm{f}\left(T_{a}\right)$ using the $\delta_{\mathrm{as}} \mathrm{IR}$ band at $1596 \mathrm{~cm}^{-1}$ at $300 \mathrm{~K}$ which is common to the two $\mathrm{NH}_{3 a d s-\mathrm{L}}$ species. Equations (4) and (5) do not allow one obtaining a theoretical curve overlapped with the experimental data in the full coverage whatever the set of $\mathrm{E}_{0}$ and $\mathrm{E}_{1}$ values. This is consistent with the fact that the two $\mathrm{NH}_{3 a d s-\mathrm{L}}$ species have significantly different heats of adsorption. However, the individual heats of adsorption of the $\mathrm{NH}_{3 \text { ads-L1 }}$ and $\mathrm{NH}_{3 \text { ads-L2 }}$ species can be determined by comparison of the experimental data with the theoretical average coverage provided by [18]:

$$
\theta_{\mathrm{th}}\left(T_{a}, P_{a}\right)=x_{1} \theta_{\mathrm{L} 1}\left(T_{a}, P_{a}\right)+x_{2} \theta_{\mathrm{L} 2}\left(T_{a}, P_{a}\right)
$$

where $\theta_{\mathrm{L} 1}\left(T_{a}, P_{a}\right)$ and $\theta_{\mathrm{L} 2}\left(T_{a}, P_{a}\right)$ are the theoretical coverages of $\mathrm{NH}_{3 a d s-\mathrm{L} 1}$ and $\mathrm{NH}_{3 a d s-\mathrm{L} 2}$ respectively provided by Equations (4) and (5) and $x_{1}$ and $x_{2}$ represent the contribution (in fraction) of each $\mathrm{NH}_{3 a d s-\mathrm{L}}$ species to the IR band at saturation of the L1 and L2 sites. For instance, curve c in Figure 4, which overlaps the experimental data is obtained using in Equation (6): $x_{1}=0.73$ and $x_{2}=0.27, \mathrm{E}_{\mathrm{L} 1}(1)=56 \mathrm{~kJ} / \mathrm{mol}, \mathrm{E}_{\mathrm{L} 1}(0)=$ $105 \mathrm{~kJ} / \mathrm{mol}, \mathrm{E}_{\mathrm{L} 2}(1)=105 \mathrm{~kJ} / \mathrm{mol}, \mathrm{E}_{\mathrm{L} 2}(0)=160 \mathrm{~kJ} / \mathrm{mol}$. The heats of adsorption are consistent with those obtained using the $\delta_{\mathrm{S}}$ IR bands (curves a and $\mathrm{b}$ in Figure 4) whereas $x_{1}$ and $x_{2}$ are consistent with the values provided by decomposition of the $\delta_{\mathrm{s}} \mathrm{IR}$ band at $300 \mathrm{~K}$.

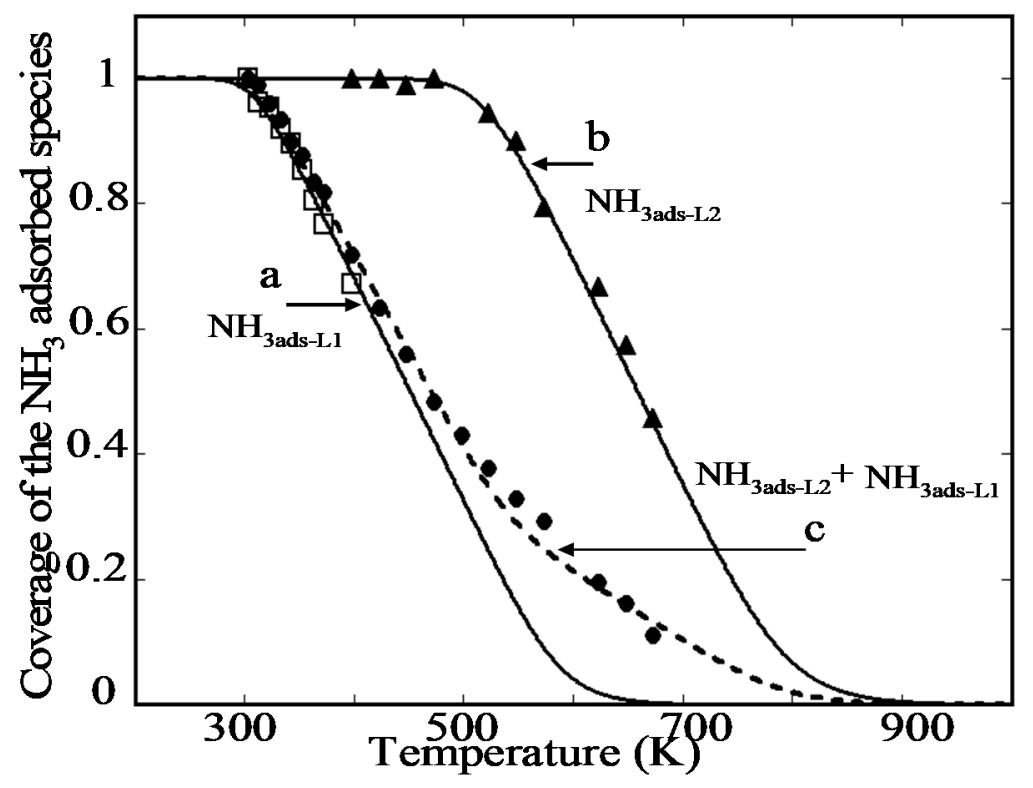

Figure 4. Heats of adsorption of the adsorbed $\mathrm{NH}_{3}$ species on $\mathrm{TiO}_{2}-\mathrm{P} 25$ using the AEIR method. $\boldsymbol{\Delta}$ and $\square$ coverages of the $\mathrm{NH}_{3 \text { ads-L2 }}$ and $\mathrm{NH}_{3 \text { ads-L1 }}$ adsorbed species respectively using their $\delta_{\mathrm{s}}$ IR bands; full lines: (a) and (b) theoretical coverages of the $\mathrm{NH}_{3 \text { ads-L1 }}$ and $\mathrm{NH}_{3 \text { ads-L2 }}$ species respectively using Equations (4) and (5) with $\mathrm{E}_{\mathrm{L} 1}(1)=56 \mathrm{~kJ} / \mathrm{mol}, \mathrm{E}_{\mathrm{L} 1}(0)=102 \mathrm{~kJ} / \mathrm{mol}, \mathrm{E}_{\mathrm{L} 2}(1)=102 \mathrm{~kJ} / \mathrm{mol}$ and $\mathrm{E}_{\mathrm{L} 2}(0)=$ $160 \mathrm{~kJ} / \mathrm{mol}$; $\bullet$ average coverage of the $\mathrm{NH}_{3 \text { ads-L1 }}$ and $\mathrm{NH}_{3 \text { ads-L2 }}$ species using their common $\delta_{\text {as }}$ IR band at $1596 \mathrm{~cm}^{-1}$; (c) theoretical evolution of the average coverage of the $\mathrm{NH}_{3 a d s-\mathrm{L}}$ species using Equation (6) considering $x_{1}=0.73$ and $x_{2}=0.27$ for the $\mathrm{NH}_{3 \text { ads-L1 }}$ and $\mathrm{NH}_{3 \text { ads-L2 }}$ species respectively and with heats of adsorption of $\mathrm{E}_{\mathrm{L} 1}(1)=56 \mathrm{~kJ} / \mathrm{mol}, \mathrm{E}_{\mathrm{L} 1}(0)=105 \mathrm{~kJ} / \mathrm{mol}, \mathrm{E}_{\mathrm{L} 2}(1)=105 \mathrm{~kJ} / \mathrm{mol}$ and $\mathrm{E}_{\mathrm{L} 2}(0)$ $=160 \mathrm{~kJ} / \mathrm{mol}$ (see the text for more details).

This procedure of the AEIR method using Equation (6) is of particular interest for the measurement of the individual heats of adsorption of $\mathrm{NH}_{3 a d s-\mathrm{L}}$ species on sulfated $\mathrm{TiO}_{2}$ containing catalysts because the strong $v(\mathrm{~S}=\mathrm{O})$ IR band of the sulfate groups prevents using the $\delta_{\mathrm{S}}$ IR band of the $\mathrm{NH}_{3 \text { ads-L }}$ species and only their common $\delta_{\text {as }}$ IR band can be exploited by the AEIR method [83]. Similarly the deposition of $\mathrm{V}_{2} \mathrm{O}_{5}$ and / or $\mathrm{WO}_{3}$ on $\mathrm{TiO}_{2}-\mathrm{P} 25$ [84] decreases the IR transmission of the solid below $\approx 1200 \mathrm{~cm}^{-1}$ 
preventing using the decomposition of the $\delta_{\mathrm{s}} \mathrm{IR}$ band of the $\mathrm{NH}_{3 \text { ads-L }}$ species as shown in Figure 5 for the adsorption of $0.1 \% \mathrm{NH}_{3} / \mathrm{He}$ on $6 \% \mathrm{WO}_{3} / \mathrm{TiO}_{2}$. Moreover, this deposition leads to the presence of strong Brønsted and Lewis sites as shown by the evolutions of the IR bands of the $\mathrm{NH}_{3 a d s-\mathrm{L}}$ (i.e., IR band at $\left.1602 \mathrm{~cm}^{-1}\right)$ and $\mathrm{NH}_{4}^{+}\left(1445 \mathrm{~cm}^{-1}\right)$ species in Figure 5 during the increase in $T_{a}$ indicating that the two species are present at $T_{a}>673 \mathrm{~K}$. The IR spectra in Figure 5 and the AEIR method give from Equation (6) the individual heats of adsorption of (a) two $\mathrm{NH}_{3 a d s-\mathrm{L}}$ species using the IR band at $1602 \mathrm{~cm}^{-1}$ and (b) two $\mathrm{NH}_{4}{ }^{+}$species using the IR band at $1445 \mathrm{~cm}^{-1}$ [84].

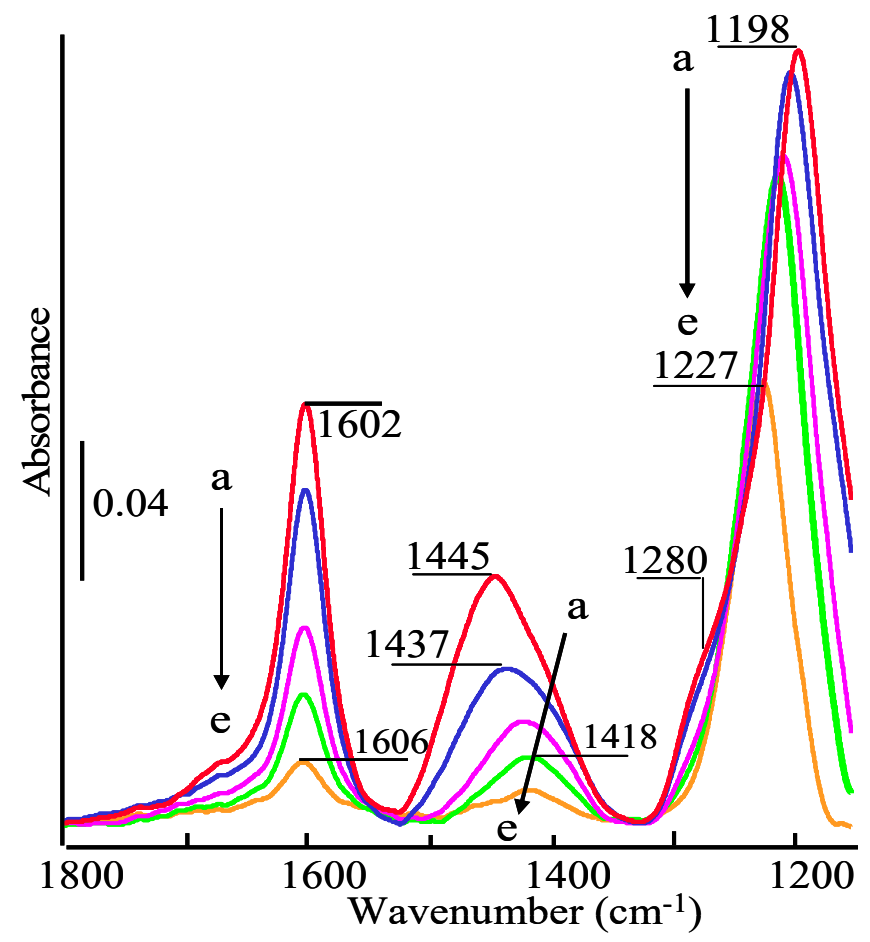

Figure 5. IR bands of adsorbed $\mathrm{NH}_{3}$ species after adsorption of $0.1 \% \mathrm{NH}_{3} / \mathrm{He}$ on $6 \% \mathrm{WO}_{3} / \mathrm{TiO}_{2}-\mathrm{P} 25$ pretreated at $713 \mathrm{~K}$ in helium as a function of adsorption temperature $T_{a}$ : (a-e) $T_{a}=300,373,498$, 573 and $673 \mathrm{~K}$.

\subsection{Application of the AEIR Method to Different Topics Relevant of Heterogeneous Catalysis}

The AEIR method can be applied using either IR transmission or reflectance mode. In IR transmission, the microreactor IR cell must associate a low path length and high temperatures [46]. In DRIFT mode, temperature gradients in the solid sample and thermal/chemical stability of the sealing material/IR windows (i.e., presence of $\mathrm{H}_{2} \mathrm{O}$ ) must be taken into account [56,75]. Indeed, the level of the performances of the IR cells is dependent on the heats of adsorption of the adsorbed species of interest: strongly adsorbed species such as L CO species on Pt particles impose using high temperatures to observe the decrease in their coverage in isobaric conditions. Note that the AEIR method does not impose a variation of the coverage in the range 1-0: experiments in the temperature range corresponding to the beginning of the decrease in the coverage with spectra representative of the linear section of the isobar (Figures 2 and 4 ) provide the heats of adsorption of the adsorbed species [53].

The design of the experiments associated to the AEIR method is simple as compared to others analytical procedures dedicated to the measurement of the heats of adsorption. This permits the application of the method to study the impacts of different parameters associated to the catalyst preparation on the individual heats of adsorption of coadsorbed species. For instance, for the adsorption of $\mathrm{CO}$ on metal particles supported on metal oxides, the AEIR method permits to study the impacts of: the precursors of the metal particles [86,87]; the nature of the support [88,89]; the metal dispersion [55] and the deposition 
of additives (i.e., $\mathrm{K}$ on $\mathrm{Pt} / \mathrm{Al}_{2} \mathrm{O}_{3}$ [90]). Similarly the AEIR method allows studying the geometric and electronic effects due to the formation of bimetallic particles via the changes in the nature of the adsorbed $\mathrm{CO}$ species and in their heats of adsorption respectively. For instance, the AEIR method reveals that the insertion of $\mathrm{Sn}$ in Pd particles [91] leads to the total disappearance of the bridged CO species due to a geometric effect. Moreover, the heat of adsorption of the $\mathrm{L} \mathrm{CO}$ species on $\mathrm{Pd}^{\circ}$ sites, which varies linearly with its coverage from $E_{0}=92 \mathrm{~kJ} / \mathrm{mol}$ to $E_{1}=54 \mathrm{~kJ} / \mathrm{mol}$ on monometallic particles, is slightly modified on the Pd-Sn bimetallic particles: $\mathrm{E}_{0}=90 \mathrm{~kJ} / \mathrm{mol}$ and $\mathrm{E}_{1}=50 \mathrm{k} / \mathrm{mol}$, indicating a very small electronic effect. Similarly, Meunier et al. have used the AEIR method in DRIFT mode to study the impacts of the insertion of $\mathrm{Zn}$ on $\mathrm{Pd}^{\circ}$ sites of a $\mathrm{Pd} / \mathrm{CeO}_{2}$ catalyst [92]. The insertion on $\mathrm{Zn}$ suppresses the $\mathrm{BCO}$ species due to a geometric effect (as for the Pd-Sn particles [91]) whereas the heat of adsorption of the L CO species for Pd-Zn particles reduced at $773 \mathrm{~K}$ varies from $\mathrm{E}_{0}=105 \pm 5 \mathrm{~kJ} / \mathrm{mol}$ to $\mathrm{E}_{1}=68 \pm 5 \mathrm{~kJ} / \mathrm{mol}$ revealing a modest electronic effect of $\mathrm{Zn}$. The same group has used the AEIR method to study the electronic effect of the insertion on $\mathrm{Sn}$ in $\mathrm{Pt}^{\circ}$ particles supported on $\mathrm{Al}_{2} \mathrm{O}_{3}$ revealing a strong electronic effect with a heat of adsorption at low coverage half of that on the monometallic particles [93].

The AEIR method is well adapted to the study of the individual heats of adsorption of adsorbed $\mathrm{CO}$ species on metal particles which is of interest either for the characterization of the solid using $\mathrm{CO}$ as a probe or for the EMA of catalytic reactions involving CO as reactant. This explains the interest of different groups for its application. For instance, Collins et al. [94] have applied the method to measure the individual heats of adsorption of one $\mathrm{L}$ and two $\mathrm{B} \mathrm{CO}$ species on the Pd sites of a $2 \% \mathrm{Pd} / \mathrm{SiO}_{2}$ catalyst: the values of the heats of adsorption of the main $B$ CO species $E_{0}=168 \mathrm{~kJ} / \mathrm{mol}$ and $E_{1}=62 \mathrm{~kJ} / \mathrm{mol}$ are consistent with those measured on a Pd/ $\mathrm{Al}_{2} \mathrm{O}_{3}$ catalyst [71] (see Table 1). Similarly, Chen et al. [95] have used the AEIR procedure in DRIFT mode to measure the heats of adsorption of two coadsorbed $\mathrm{L}_{1}$ and $\mathrm{L}_{2} \mathrm{CO}$ species on $\mathrm{Cu}$ particles supported on $\mathrm{SiO}_{2}$ : IR bands at 2134 and $2119 \mathrm{~cm}^{-1}$ respectively, in relationship with the water-gas shift reaction. The $E_{0}$ and $E_{1}$ values are of $51 \mathrm{~kJ} / \mathrm{mol}$ and $39 \mathrm{~kJ} / \mathrm{mol}$ for the $\mathrm{L} 1$ and $70 \mathrm{~kJ} / \mathrm{mol}$ and $46 \mathrm{~kJ} / \mathrm{mol}$ for $\mathrm{L}_{2} \mathrm{CO}$ species. These values are consistent with those measured on a Cu/ $\mathrm{Al}_{2} \mathrm{O}_{3}$ catalyst [62] (see Table 1). Rioux et al. [96] have used the AEIR method in diffuse reflectance mode for the measurement of the heat of adsorption of the $\mathrm{L} \mathrm{CO}$ species on $2.69 \% \mathrm{Pt} / \mathrm{SiO}_{2}$ (mesoporous silica: SBA-15, Pt particles $2.9 \mathrm{~nm}$ ) using 10\% CO/He showing a linear decrease with the increase in the coverage from $\mathrm{E}_{0}=167 \mathrm{~kJ} / \mathrm{mol}$ to $\mathrm{E}_{1}=125 \mathrm{~kJ} / \mathrm{mol}$. The $\mathrm{E}_{1}$ value is consistent with that measured on $2.9 \%$ $\mathrm{Pt} / \mathrm{Al}_{2} \mathrm{O}_{3}$ (Table 1) while that a low coverage is slightly lower probably due to the nature of the support and the type of Pt particles due to the preparation method.

Diemant et al. [97] have used Equations (4) and (5) for the exploitation of the coverage of a L CO species on planar $\mathrm{Au} / \mathrm{TiO}_{2}$ model catalysts with different particle sizes obtained from Polarization Modulation-IRAS (PM-IRAS) spectra. They show that the evolutions of the experimental coverages in isobaric condition $\left(\mathrm{P}_{\mathrm{CO}} \approx 10 \mathrm{mbar}\right)$ are consistent with the theoretical curves. They reveal the significant impact of the particles size $\Phi$ on the heats of adsorption of the L CO species: i.e., $E_{0}$ decreases from $74 \mathrm{~kJ} / \mathrm{mol}$ to $62 \mathrm{~kJ} / \mathrm{mol}$ for $\Phi$ in the range of 2-4 nm [97]. The values at low and high coverages for $\Phi=2 \mathrm{~nm}: 74 \mathrm{~kJ} / \mathrm{mol}$ and $40 \mathrm{~kJ} / \mathrm{mol}$ are consistent with those determined on a conventional $\mathrm{Au} / \mathrm{TiO}_{2}$ catalyst [61] (see Table 1). This shows that the AEIR method may allow us studying the impacts of the material gap between conventional catalysts and model surfaces on a key parameter of catalytic reactions.

Thus the AEIR method is often used to reinforce studies using the adsorption of a gas as a probe of the surface properties of a catalyst by providing via the individual heats of adsorption of the adsorbed species a quantification of the strength of the sites. For instance, this was one of the aims studying the modifications of the Lewis and Brønsted acidic sites by the deposition of $\mathrm{WO}_{3}$ and $\mathrm{V}_{2} \mathrm{O}_{5}$ groups on sulfated and sulfate free $\mathrm{TiO}_{2}$ supports species $[18,83,84]$. However, the AEIR method has been clearly developed as contribution to the EMA of catalytic reactions. In this field one of its interest is that it allows one studying the impact of the presence of a second gas (reactant or not) such as $\mathrm{O}_{2}, \mathrm{H}_{2}$ and $\mathrm{H}_{2} \mathrm{O}$ on the heats of adsorption of adsorbed $\mathrm{CO}$ species on $\mathrm{Pt} / \mathrm{Al}_{2} \mathrm{O}_{3}$ [98]. Particularly, the method provides experimental data on the change in the coverages of the different adsorbed species due to 
the coadsorption. These data can be modeled using theoretical coverages obtained from the Temkin formalism for competitive chemisorption without [15] and with [16] transformation of the reactants which is a key step of the EMA of a catalytic reaction such as for $\mathrm{CO} / \mathrm{H}_{2}$ on $\mathrm{Pt} / \mathrm{Al}_{2} \mathrm{O}_{3}[15,16]$.

\section{Conclusions}

The AEIR method developed and applied during the last twenty years for the characterization of individual heats of adsorption of coadsorbed species formed by the adsorption of a gas on a solid catalyst, constitutes a tool for the development of the experimental microkinetic approach of gas/solid heterogeneous catalysis using conventional powdered catalysis. For each adsorbed species, the method allows, from the evolution of their characteristic IR bands in isobaric conditions to measure their individual heats of adsorption at different coverages via the validation of mathematical expressions of the adsorption coefficients and adsorption models. These data allow an accurate modeling of the two first surface elementary steps of any gas/solid catalytic reaction taking into account the diversity of the adsorption sites on a conventional catalyst. The design of the experiment for the AEIR method is easy as compared to others classical methods: a single isobar is needed using either a pellet of catalyst in IR transmission mode or sized catalyst particles for IR reflectance mode. This facilitates the use of the method for the study of the impacts of the modifications of the catalyst on the heats of adsorption such as the natures of the precursors, supports and additives and the formation of bimetallic particles. Moreover, the fact that the procedure can be applied on model surfaces [97] permits studying the impact of the material gap on an important thermodynamic parameters controlling the coverage of the surface during a catalytic reaction.

Funding: This research received no external funding.

Acknowledgments: I thank the different co-workers and Ph.D. students who have contributed to the development of the AEIR method and who appear as co-authors in the different references of the present work more particularly O. Dulaurent, A. Bourane, S. Derrouiche, P. Gravejat, J. Couble, and F. Giraud. Thanks are due to the industrial groups which appear in the different references for their financial supports more particularly FAURECIA which has allowed initiating the development of this method.

Conflicts of Interest: The authors declare no conflict of interest.

\section{References}

1. Dumesic, J.A.; Rudd, D.F.; Aparicio, L.M.; Rekoske, J.E.; Treviño, A.A. The Microkinetics of Heterogeneous Catalysis; ACS Professional Reference Book; An American Chemical Society Publication: Washington, DC, USA, 1993.

2. Stoltze, P. Microkinetic Simulation of Catalytic Reactions. Prog. Surf. Sci. 2000, 65, 65-150. [CrossRef]

3. Lynggaard, H.; Andreasen, A.; Stegelmann, C.; Stoltze, P. Analysis of Simple Kinetic Models in Heterogeneous Catalysis. Prog. Surf. Sci. 2004, 77, 71-137. [CrossRef]

4. Fishtik, I.; Callaghan, A.; Datta, R. Reaction Route Graphs. I. Theory and Algorithm. J. Phys. Chem. B 2004, 108, 5671-5682. [CrossRef]

5. Thybaut, J.W.; Marin, G.B. Single-Event MicroKinetics: Catalyst Design for Complex Reaction Networks. J. Catal. 2013, 308, 352-362. [CrossRef]

6. Van Helden, P.; van den Berg, J.A.; Coetzer, R.L.J.A. Statistical Approach to Microkinetic Analysis. Ind. Eng. Chem. Res. 2012, 51, 6631-6640. [CrossRef]

7. Hinrichsen, O.; Rosowski, E.; Muhler, M.; Ertl, G. The Microkinetic of Ammonia Synthesis Catalyzed by Cesium-promoted Supported Ruthenium. Chem. Eng. Sci. 1996, 51, 1683-1690. [CrossRef]

8. Dahl, S.; Sehested, J.; Jacobsen, C.J.H.; Törnqvist, E.; Chorkendorff, I. Surface Science Based Microkinetic Analysis of Ammonia Synthesis over Ruthenium Catalysts. J. Catal. 2000, 192, 391-399. [CrossRef]

9. Mhadeshwar, A.B.; Kitchin, J.R.; Barteau, M.A.; Vlachos, D.G. The Role of Adsorbate-adsorbate Interactions in the Rate Controlling Step and the most Abundant Reaction Intermediate of $\mathrm{NH}_{3}$ Decomposition on $\mathrm{Ru}$. Catal. Lett. 2004, 96, 13-22. [CrossRef]

10. Xu, J.; Clayton, R.; Balakotaiah, V.; Harold, M.P. Experimental and Microkinetic Modeling of Steady-state NO Reduction by $\mathrm{H}_{2}$ on Pt/BaO/ $/ \mathrm{Al}_{2} \mathrm{O}_{3}$ Monolith Catalysts. Appl. Catal. B Environ. 2008, 77, 395-408. [CrossRef] 
11. Storsæter, S.; Chen, D.; Holmen, A. Microkinetic Modelling of the Formation of C1 and C2 Products in the Fischer-Tropsch Synthesis over Cobalt Catalysts. Surf. Sci. 2006, 600, 2051-2063. [CrossRef]

12. Stegelmann, C.; Stoltze, P. Microkinetic Analysis of Transient Ethylene Oxidation Experiments on Silver. J. Catal. 2004, 226, 129-137. [CrossRef]

13. Bourane, A.; Bianchi, D. Oxidation of $\mathrm{CO}$ on a Pt/ $\mathrm{Al}_{2} \mathrm{O}_{3}$ Catalyst: From the Surface Elementary Steps to Light-Off Tests. 1. Kinetic Study of the Oxidation of the Linear CO Species. J. Catal. 2001, 202, 34-44. [CrossRef]

14. Bourane, A.; Bianchi, D. Oxidation of $\mathrm{CO}$ on a Pt $/ \mathrm{Al}_{2} \mathrm{O}_{3}$ Catalyst: Form the Elementary Steps to Light-off Tests. 5-Experimental and Kinetic Modeling of Light-off Tests in Excess of $\mathrm{O}_{2}$. J. Catal. 2004, 222, 499-510. [CrossRef]

15. Couble, J.; Bianchi, D. Experimental Microkinetic Approach of the $\mathrm{CO} / \mathrm{H}_{2}$ Reaction on $\mathrm{Pt} / \mathrm{Al}_{2} \mathrm{O}_{3}$ using the Temkin Formalism. 1. Competitive Chemisorption between Adsorbed CO and Hydrogen Species in the Absence of Reaction. J. Catal. 2017, 352, 672-685. [CrossRef]

16. Couble, J.; Bianchi, D. Experimental Microkinetic Approach of the $\mathrm{CO} / \mathrm{H}_{2}$ Reaction on $\mathrm{Pt} / \mathrm{Al}_{2} \mathrm{O}_{3}$ using the Temkin Formalism. 2. Coverages of the Adsorbed CO and Hydrogen species during the Reaction and Rate of the $\mathrm{CH}_{4}$ Production. J. Catal. 2017, 352, 686-698. [CrossRef]

17. Haaland, D. Infrared Sudies of $\mathrm{CO}$ adsorbed on $\mathrm{Pt} / \mathrm{Al}_{2} \mathrm{O}_{3}$ : Evidence for $\mathrm{CO}$ Bonded in 3-Fold Coordination. Surf. Sci. 1987, 185, 1-14. [CrossRef]

18. Giraud, F.; Geantet, C.; Guilhaume, N.; Gros, S.; Porcheron, L.; Kanniche, M.; Bianchi, D. Experimental Microkinetic Approach of De- $\mathrm{NO}_{x}$ by $\mathrm{NH}_{3}$ on $\mathrm{V}_{2} \mathrm{O}_{5} / \mathrm{WO}_{2} / \mathrm{TiO}_{2}$ Catalysts: Part 1 -Individual Heats of Adsorption of Adsorbed $\mathrm{NH}_{3}$ species on a Sulfate-free $\mathrm{TiO}_{2}$ Support using adsorption isobars. J. Phys. Chem. C 2014, 118, 15664-15676. [CrossRef]

19. Tompkins, F.C. Chemisorption of Gases on Metal; Academic Press: London, UK, 1978.

20. Cardona-Martinez, N.; Dumesic, J.A. Application of Adsorption Microcalorimetry to the Study of heterogeneous catalysis. Adv. Catal. 1992, 38, 149-237.

21. Spiewak, B.E.; Dumesic, J.A. Microcalorimetric measurements of differential heats of adsorption on reactive catalyst surfaces. Thermochim. Acta 1996, 290, 43-53. [CrossRef]

22. Podkolzin, S.G.; Shen, J.; de Pablo, J.J.; Dumesic, J.A. Equilibrated Adsorption of CO on Silica-Supported Pt Catalysts. J. Phys. Chem. B 2000, 104, 4169-4180. [CrossRef]

23. Watwe, R.M.; Spiewak, B.E.; Cortright, R.D.; Dumesic, J.A. Density Functional Theory (DFT) and Microcalorimetric Investigations of CO adsorption on Pt clusters. Catal. Lett. 1998, 51, 139-147. [CrossRef]

24. Falconer, J.L.; Schwarz, J.A. Temperature-Programmed Desorption and Reaction: Applications to supported Catalysts. Catal. Rev. Sci. Eng. 1983, 25, 141-227. [CrossRef]

25. Lemaitre, J.C. Temperature Programmed methods. In Characterization of Heterogeneous Catalysts; Marcel Dekker: New York, NY, USA, 1984.

26. Gorte, R.J. Design Parameters for Temperature Programmed Desorption from Porous Catalysts. J. Catal. 1982, 75, 164-174. [CrossRef]

27. Demmin, R.A.; Gorte, R.J. Design Parameters for Temperature-Programmed Desorption from a Packed Bed. J. Catal. 1984, 90, 32-39. [CrossRef]

28. Rieck, J.S.; Bell, A.T. Influence of Adsorption and Mass Transfer Effects on Temperature-Programmed Desorption from Porous Catalysts. J. Catal. 1984, 85, 143-153. [CrossRef]

29. Efsthathiou, A.; Bennett, C.O. Enthalpy and Entropy of $\mathrm{H}_{2}$ Adsorption on $\mathrm{Rh} / \mathrm{Al}_{2} \mathrm{O}_{3}$ Measured by Temperature-Programmed Desorption. J. Catal. 1990, 124, 116-126. [CrossRef]

30. Derrouiche, S.; Bianchi, D. Heats of Adsorption Using Temperature Programmed Adsorption Equilibrium: Application to the Adsorption of $\mathrm{CO}$ on $\mathrm{Cu} / \mathrm{Al}_{2} \mathrm{O}_{3}$ and $\mathrm{H}_{2}$ on $\mathrm{Pt} / \mathrm{Al}_{2} \mathrm{O}_{3}$. Langmuir 2004, 20, 4489-4497. [CrossRef] [PubMed]

31. Xia, X.; Strunk, J.; Litvinov, S.; Muhler, M. Influence of Re-adsorption and Surface Heterogeneity on the Microkinetic Analysis of Temperature-Programmed Desorption Experiments. J. Phys. Chem. C 2007, 111, 6000-6008. [CrossRef]

32. Kottke, M.L.; Greenler, R.G.; Tompkins, H.G. An Infrared Spectroscopy Study of Carbon Monoxide adsorbed on polycristalline gold using the reflection-Absorption Technique. Surf. Sci. 1972, 32, 231-243. [CrossRef]

33. Richardson, H.H.; Baumann, C.; Ewing, G.E. Infrared Spectroscopy and Thermodynamic Measurement of $\mathrm{CO}$ on $\mathrm{NaCl}$ Films. Surf. Sci. 1987, 185, 15-35. [CrossRef] 
34. Truong, C.M.; Rodriguez, J.A.; Goodman, D.W. CO Adsorption Isotherms on Cu(100) at Elevated Pressures and Temperatures using Infrared Reflection Absorption Spectroscopy. Surf. Sci. Lett. 1992, 271, L385-L391. [CrossRef]

35. Kuhn, W.K.; Szanyi, J.; Goodman, D.W. Adsorption Isobars for CO on Pd/Ta(110) at Elevated Pressures and Temperatures using Infrared Reflection-Absorption Spectroscopy. Surf. Sci. 1994, 303, 377-385. [CrossRef]

36. Szanyi, J.; Goodman, D.W. CO Oxidation on Palladium. 1. A Combined Kinetic-Infrared Reflection Absorption Spectroscopic Study of Pd(100). J. Phys. Chem. 1994, 98, 2972-2977. [CrossRef]

37. Szanyi, J.; Kuhn, W.K.; Goodman, D.W. CO Oxidation on Palladium. 2. A Combined Kinetic-Infrared Reflection Absorption Spectroscopic Study of Pd(111). J. Phys. Chem. 1994, 98, 2978-2981. [CrossRef]

38. Kuhn, W.K.; Szanyi, J.; Goodman, D.W. CO Adsorption on Pd(111): The Effects of Temperature and Pressure. Surf. Sci. Lett. 1992, 274, L611-L618. [CrossRef]

39. Paukshtis, E.A.; Soltanov, R.I.; Yurchenko, E.N. Determination of the Strength of Aprotic Acidic Centers on Catalyst Surfaces from the IR Spectra of Adsorbed Carbon Monoxide. React. Kinet. Catal. Lett. 1981, 16, 93-96. [CrossRef]

40. Paukshtis, E.A.; Soltanov, R.I.; Yurchenko, E.N. Determination of the Strength of Lewis Acid Centers via IR Spectroscopic Measurement of Adsorbed Pyridine. React. Kinet. Catal. Lett. 1982, 19, 105-108. [CrossRef]

41. Beebe, T.P.; Gelin, P.; Yates, J.T., Jr. Infrared Spectroscopic Observation of Surface Bonding in Physical Adsorption: The Physical Adsorption of $\mathrm{CO}$ on $\mathrm{SiO}_{2}$ Surfaces. Surf. Sci. 1984, 148, 526-550. [CrossRef]

42. Ballinger, T.H.; Yates, J.T., Jr. IR Spectroscopic Detection of Lewis Acid Sites on $\mathrm{A}_{2} \mathrm{O}_{3}$ Using Adsorbed CO. Correlation with Al-OH Group Removal. Langmuir 1991, 7, 3041-3045. [CrossRef]

43. Garrone, E.; Bolis, V.; Fubini, B.; Morterra, C. Thermodynamic and Spectroscopic Characterization of Heterogeneity among Adsorption Sites: CO on Anatase at Ambient Temperature. Langmuir 1989, 5, 892-899. [CrossRef]

44. Bolis, V.; Morterra, C.; Fubini, B.; Ugliengo, P.; Garrone, E. Temkin-Type Model for the Description of Induced Heterogeneity: CO Adsorption on Group 4 Transition Metal Dioxides. Langmuir 1993, 9, 1521-1528. [CrossRef]

45. Garrone, E.; Fubini, B.; Bonelli, B.; Onida, B.; Otero Areán, C. Thermodynamics of CO Adsorption on the Zeolite Na-ZSM-5 A Combined Microcalorimetric and FTIR Spectroscopic Study. Phys. Chem. Chem. Phys. 1999, 1, 513-518. [CrossRef]

46. Chafik, T.; Dulaurent, O.; Gass, J.L.; Bianchi, D. Heat of Adsorption of Carbon Monoxide on a $\mathrm{Pt} / \mathrm{Rh} / \mathrm{CeO}_{2} / \mathrm{Al}_{2} \mathrm{O}_{3}$ Three-Way Catalyst Using in-Situ Infrared Spectroscopy at High Temperatures. J. Catal. 1998, 179, 503-514. [CrossRef]

47. Soma-Noto, Y.; Sachtler, W.M.H. Infrared Spectra of Carbon Monoxide Adsorbed on Supported Palladium and Palladium-Silver Alloys. J. Catal. 1974, 32, 315-324. [CrossRef]

48. Barth, R.; Pitchai, R.; Anderson, R.L.; Verykios, X.E. Thermal Desorption-Infrared Study of Carbon Monoxide Adsorption by Alumina-Supported Platinum. J. Catal. 1989, 116, 61-70. [CrossRef]

49. Bourane, A.; Dulaurent, O.; Chandes, K.; Bianchi, D. Heats of Adsorption of the Linear CO Species on a Pt $/ \mathrm{Al}_{2} \mathrm{O}_{3}$ Catalyst using FTIR Spectroscopy: Comparison between TPD and Adsorption Equilibrium Procedures. Appl. Catal. A Gen. 2001, 214, 193-202. [CrossRef]

50. Kellner, C.S.; Bell, A.T. Studies of Carbon Monoxide Hydrogenation over Alumina Supported Ruthenium. J. Catal. 1981, 71, 296-307. [CrossRef]

51. Kohler, M.A.; Cant, N.W.; Wainwright, M.S.; Trim, D.L. Infrared Spectroscopic Studies of Carbon Monoxide Adsorbed on a Series of Silica-Supported Copper Catalysts in Different Oxidation States. J. Catal. 1989, 117, 188-201. [CrossRef]

52. Clarke, D.B.; Suzuki, I.; Bell, A.T. An Infrared Study of the Interaction of $\mathrm{CO}$ and $\mathrm{CO}_{2}$ with $\mathrm{Cu} / \mathrm{SiO}$. J. Catal. 1993, 142, 27-36. [CrossRef]

53. Dulaurent, O; Bianchi, D. Adsorption Isobars for $\mathrm{CO}$ on a Pt $/ \mathrm{Al}_{2} \mathrm{O}_{3}$ Catalyst at High Temperatures using FTIR Spectroscopy: Isosteric Heat of Adsorption and Adsorption Model. Appl. Catal. A Gen. 2000, 196, 271-280. [CrossRef]

54. Bourane, A.; Dulaurent, O.; Bianchi, D. Heats of Adsorption of Linear and Multibound Adsorbed CO Species on a $\mathrm{Pt} / \mathrm{Al}_{2} \mathrm{O}_{3}$ Catalyst Using in Situ Infrared Spectroscopy under Adsorption Equilibrium. J. Catal. 2000, 196, 115-125. [CrossRef] 
55. Bourane, A.; Bianchi, D. Heats of Adsorption of the Linear $\mathrm{CO}$ species on $\mathrm{Pt} / \mathrm{Al}_{2} \mathrm{O}_{3}$ using Infrared Spectroscopy: Impact of the Pt Dispersion. J. Catal. 2003, 218, 447-452. [CrossRef]

56. Couble, J.; Gravejat, P.; Gaillard, F.; Bianchi, D. Quantitative Analysis of Infrared Spectra of Adsorbed Species using Transmission and Diffuse Reflectance Modes. Case Study: Heats of Adsorption of $\mathrm{CO}$ on $\mathrm{TiO}_{2}$ and $\mathrm{CuO} / \mathrm{Al}_{2} \mathrm{O}_{3}$. Appl. Catal. A Gen. 2009, 371, 99-107. [CrossRef]

57. Couble, J.; Bianchi, D. Heats of Adsorption of Linearly Adsorbed CO Species on $\mathrm{Co}^{2+}$ and $\mathrm{Co}^{\circ} \mathrm{Sites}$ of Reduced $\mathrm{Co} / \mathrm{Al}_{2} \mathrm{O}_{3}$ Catalysts in Relationship with the $\mathrm{CO} / \mathrm{H}_{2}$ Reaction. Appl. Catal. A 2012, 445-446, 1-13. [CrossRef]

58. Gravejat, P.; Derrouiche, S.; Farrussengn, D.; Lombaert, K.; Mirodatos, C.; Bianchi, D. Heats of Adsorption of Linear and Bridged CO Species Adsorbed on a $3 \% \mathrm{Ag} / \mathrm{Al}_{2} \mathrm{O}_{3}$ Catalyst Using in situ FTIR Spectroscopy under Adsorption Equilibrium. J. Phys. Chem. C 2007, 111, 9496-9503. [CrossRef]

59. Müslehiddinoglu, J.; Vannice, M.A. CO Adsorption on Supported and Promoted Ag Epoxidation Catalysts. J. Catal. 2003, 213, 305-320. [CrossRef]

60. Dulaurent, O.; Bianchi, D. Adsorption Model and Heats of Adsorption for Linear CO Species Adsorbed on $\mathrm{ZrO}_{2}$ and $\mathrm{Pt} / \mathrm{ZrO}_{2}$ using FTIR Spectroscopy. Appl. Catal. A Gen. 2001, 207, 211-219. [CrossRef]

61. Derrouiche, S.; Gravejat, P.; Bianchi, D. Heats of Adsorption of Linear CO Species Adsorbed on the $\mathrm{Au}^{\circ}$ and $\mathrm{Ti}^{+}$Sites of a $\% \mathrm{Au} / \mathrm{TiO}_{2}$ Catalyst Using in Situ FTIR Spectroscopy under Adsorption Equilibrium. J. Am. Chem. Soc. 2004, 126, 13010-13015. [CrossRef] [PubMed]

62. Derrouiche, S.; Courtois, X.; Perrichon, V.; Bianchi, D. Heats of Adsorption of $\mathrm{CO}$ on a Cu/ $\mathrm{Al}_{2} \mathrm{O}_{3} \mathrm{Catalyst}$ Using FTIR Spectroscopy at High Temperatures and under Adsorption Equilibrium Conditions. J. Phys. Chem. B 2000, 104, 6001-6011.

63. Zeradine, S.; Bourane, A.; Bianchi, D. Comparison of the Coverage of the Linear CO Species on $\mathrm{Cu} / \mathrm{Al}_{2} \mathrm{O}_{3}$ Measured under Adsorption Equilibrium Conditions by Using FTIR and Mass Spectroscopy. J Phys. Chem. B 2001, 105, 7254-7267. [CrossRef]

64. Bourane, A.; Nawdali, M.; Bianchi, D. Heats of Adsorption of the Linear CO Species Adsorbed on a Ir $/ \mathrm{Al}_{2} \mathrm{O}_{3}$ Catalyst Using in Situ FTIR Spectroscopy under Adsorption Equilibrium. J. Phys. Chem. B 2002, 106, 2665-2671. [CrossRef]

65. Bourane, A.; Dulaurent, O.; Bianchi, D. Comparison of the Coverage of the Linear CO Species on $\mathrm{Pt} / \mathrm{Al}_{2} \mathrm{O}_{3}$ Measured under Adsorption Equilibrium Conditions by Using FTIR and Mass Spectroscopy. J. Catal. 2000, 195, 406-411. [CrossRef]

66. Temkin, M.I. The Kinetics of some Industrial Heterogeneous Catalytic Reactions. Adv. Catal. 1979, 28, 173-291.

67. Glasstone, S.; Laidler, K.J.; Eyring, F. The Theory of Rate Processes; McGraw-Hill Inc.: New York, NY, USA; London, UK, 1941.

68. Laidler, K.J. Chap 5: The Absolute Rates of Surface Reactions. In Catalysis; Hemmett, P.H., Ed.; Reinhold Publishing Corporation: New York, NY, USA, 1954; Volume 1.

69. Hill, T.L. An Introduction to Statistical Thermodynamics; Addison-Wesley Publishing Company, Inc.: Boston, MA, USA, 1962.

70. Hachimi, A.; Chafik, T.; Bianchi, D. Adsorption Models and Heat of Adsorption of Adsorbed Ortho Di-methyl Benzene species on Silica by using Temperature Programmed Adsorption Equilibrium methods. Appl. Catal. A Gen. 2008, 335, 220-229. [CrossRef]

71. Dulaurent, O.; Chandes, K.; Bouly, C.; Bianchi, D. Heat of Adsorption of Carbon Monoxide on a Pd/ $\mathrm{Al}_{2} \mathrm{O}_{3}$ Solid Using in Situ Infrared Spectroscopy at High Temperatures. J. Catal. 1999, 188, 237-251. [CrossRef]

72. Dulaurent, O.; Chandes, K.; Bouly, C.; Bianchi, D. Heat of Adsorption of Carbon Monoxide on a Pd/Rh Three-Way Catalyst and on a $\mathrm{Rh} / \mathrm{Al}_{2} \mathrm{O}_{3}$ Solid. J. Catal. 2000, 192, 262-272. [CrossRef]

73. Dulaurent, O.; Nawdali, M.; Bourane, A.; Bianchi, D. Heat of Adsorption of Carbon Monoxide on a $\mathrm{Ru} / \mathrm{Al}_{2} \mathrm{O}_{3}$ Catalyst using Adsorption Equilibrium Conditions at High Temperatures. Appl. Catal. A Gen. 2000, 201, 271-279. [CrossRef]

74. Derrouiche, S.; Bianchi, D. Heats of Adsorption of the Linear and Bridged CO species on a Ni/ $\mathrm{Al}_{2} \mathrm{O}_{3} \mathrm{Catalyst}$ by Using the AEIR Method. Appl. Catal. A Gen. 2006, 313, 208-217. [CrossRef]

75. Couble, J.; Bianchi, D. Heat of adsorption of the linear $\mathrm{CO}$ species adsorbed on reduced $\mathrm{Fe} / \mathrm{Al}_{2} \mathrm{O}_{3}$ catalysts using the AEIR method in diffuse reflectance mode. Appl. Catal. A Gen. 2011, 409, 28-38. [CrossRef] 
76. Lombardo, S.J.; Bell, A.T. A Review of Theoretical Models of Adsorption, Diffusion, Desorption, and Reaction of Gases on Metal Surfaces. Surf. Sci. Rep. 1991, 13,1-72. [CrossRef]

77. Foo, K.Y.; Hammed, B.H. Insights into the Modeling of Adsorption Isotherm Systems. Chem. Eng. J. 2010, 156, 2-10. [CrossRef]

78. Murzin, D.Y. Modeling of Adsorption and Kinetics in Catalysis over Induced Nonuniform Surfaces: Surface Electronic Gas Model. Ind. Eng. Chem. Res. 1995, 34, 1208-1218. [CrossRef]

79. Yang, C.H. Statistical Mechanical Aspects of Adsorption Systems Obeying the Temkin Isotherm. J. Phys. Chem. 1993, 97, 7097-7101. [CrossRef]

80. Ritter, J.A.; Kapoor, A.; Yang, R.T. Localized Adsorption with Lateral Interaction on Random and Patchwise Heterogeneous Surfaces. J. Phys. Chem. 1990, 94, 6785-6791. [CrossRef]

81. Ritter, J.A.; Al-Muhtaseb, S.A. New Model That Describes Adsorption of Laterally Interacting Gas Mixtures on Random Heterogeneous Surfaces. 1. Parametric Study and Correlation with Binary Data. Langmuir 1998, 14, 6528-6538. [CrossRef]

82. Bourane, A.; Dulaurent, O.; Salasc, S.; Sarda, C.; Bouly, C.; Bianchi, D. Heats of Adsorption of Linear NO Species on a Pt $/ \mathrm{Al}_{2} \mathrm{O}_{3}$ Catalyst Using in Situ Infrared Spectroscopy under Adsorption Equilibrium. J. Catal. 2001, 204, 77-88. [CrossRef]

83. Giraud, F.; Geantet, C.; Guilhaume, N.; Loridant, S.; Gros, S.; Porcheron, L.; Kanniche, M.; Bianchi, D. Experimental Microkinetic Approach of De- $\mathrm{NO}_{\mathrm{x}}$ by $\mathrm{NH}_{3}$ on $\mathrm{V}_{2} \mathrm{O}_{5} / \mathrm{WO}_{2} / \mathrm{TiO}_{2}$ Catalysts. 2: Impact of Superficial Sulfate and/or $\mathrm{V}_{\mathrm{x}} \mathrm{O}_{\mathrm{y}}$ groups on the Heats of Adsorption of Adsorbed $\mathrm{NH}_{3}$ species. J. Phys. Chem. C 2014, 118, 15677-15692. [CrossRef]

84. Giraud, F.; Geantet, C.; Guilhaume, N.; Loridant, S.; Gros, S.; Porcheron, L.; Kanniche, M.; Bianchi, D. Experimental Microkinetic Approach of De- $\mathrm{NO}_{x}$ by $\mathrm{NH}_{3}$ on $\mathrm{V}_{2} \mathrm{O}_{5} / \mathrm{WO}_{2} / \mathrm{TiO}_{2}$ Catalysts. 3: Impact of Superficial $\mathrm{WO}_{\mathrm{z}}$ and $\mathrm{V}_{\mathrm{x}} \mathrm{O}_{\mathrm{y}} / \mathrm{WO}_{\mathrm{z}}$ Groups on the Heats of Adsorption of Adsorbed $\mathrm{NH}_{3}$ species. J. Phys. Chem. C 2015, 119, 15401-15413. [CrossRef]

85. Giraud, F.; Couble, J.; Geantet, C.; Guilhaume, N.; Puzenat, E.; Gros, S.; Porcheron, L.; Kanniche, M.; Bianchi, D. Experimental Microkinetic Approach of De- $\mathrm{NO}_{x}$ by $\mathrm{NH}_{3}$ on $\mathrm{V}_{2} \mathrm{O}_{5} / \mathrm{WO}_{2} / \mathrm{TiO}_{2}$ Catalysts. 4 . Individual Heats of Adsorption of Adsorbed $\mathrm{H}_{2} \mathrm{O}$ Species on Sulfate-Free and Sulfated $\mathrm{TiO}_{2}$ Supports. J. Phys. Chem. C 2015, 119, 16089-16105. [CrossRef]

86. Nawdali, M.; Bianchi, D. The impact of the Ru precursor on the adsorption of $\mathrm{CO}$ on $\mathrm{Ru} / \mathrm{Al}_{2} \mathrm{O}_{3}$ : $\mathrm{Amount}$ and reactivity of the adsorbed species. Appl. Catal. A Gen. 2002, 231, 45-54. [CrossRef]

87. Derrouiche, S.; Perrichon, V.; Bianchi, D. Impact of the Residual Chlorine on the Heat of Adsorption of the Linear CO Species on $\mathrm{Cu} / \mathrm{Al}_{2} \mathrm{O}_{3}$ Catalysts. J. Phys. Chem. B 2003, 107, 8588-8591. [CrossRef]

88. Dulaurent, O.; Chandes, K.; Bouly, C.; Bianchi, D. Heat of Adsorption of Carbon Monoxide on Various Pd-Containing Solids Using in Situ Infrared Spectroscopy at High Temperatures. J. Catal. 2000, 192, 273-285. [CrossRef]

89. Pillonel, P.; Derrouiche, S.; Bourane, A.; Gaillard, F.; Vernoux, P.; Bianchi, D. Impact of the support on the heat of adsorption of the linear CO species on Pt-containing catalysts. Appl. Catal. A Gen. 2005, 278, 223-231. [CrossRef]

90. Derrouiche, S.; Gravejat, P.; Bassou, B.; Bianchi, D. Impact of Potassium on the Heats of Adsorption of Adsorbed CO species on Supported Pt Particles by Using the AEIR Method. Appl. Surf. Sci. 2007, 253, 5894-5898. [CrossRef]

91. Jbir, I.; Couble, J.; Khaddar-Zine, S.; Ksibi, Z.; Meunier, F.; Bianchi, D. Individual Heat of Adsorption of Adsorbed $\mathrm{CO}$ Species on Palladium and $\mathrm{Pd}-\mathrm{Sn}$ Nanoparticles Supported on $\mathrm{Al}_{2} \mathrm{O}_{3}$ by Using Temperature-Programmed Adsorption Equilibrium Methods. ACS Catal. 2016, 6, 2545-2558. [CrossRef]

92. Meunier, F.; Maffre, M.; Schuurmann, Y.; Colussi, S.; Trovarelli, A. Acetylene semi-hydrogenation over $\mathrm{Pd}-\mathrm{Zn} / \mathrm{CeO}_{2}$ : Relevance of $\mathrm{CO}$ adsorption and methanation as descriptors of selectivity. Catal. Commun. 2018, 105, 52-55. [CrossRef]

93. Moscu, A.; Schuurman, Y.; Veyre, L.; Thieuleux, C.; Meunier, F. Direct evidence by in situ IR CO monitoring of the formation and the surface segregation of a Pt-Sn alloy. Chem. Commun. 2014, 50, 8590-8592. [CrossRef] [PubMed]

94. Collins, S.E.; Baltanas, M.A.; Bonivardi, A.L. Heats of adsorption and activation energies of surface processes measured by infrared spectroscopy. J. Mol. Catal. A 2008, 281, 73-78. [CrossRef] 
95. Chen, C.-S.; Lai, T.-W.; Chen, C.-C. Effect of Active Sites for a Water-Gas Shift Reaction on Cu Nanoparticles. J. Catal. 2010, 273, 18-28. [CrossRef]

96. Rioux, R.M.; Hoefelmeyer, J.D.; Grass, M.; Song, H.; Niesz, K.; Yang, P.; Somorjai, G.A. Adsorption and Co-adsorption of Ethylene and Carbon Monoxide on Silica-Supported Monodisperse Pt Nanoparticles: Volumetric Adsorption and Infrared Spectroscopy Studies. Langmuir 2008, 24, 198-207. [CrossRef] [PubMed]

97. Diemant, T.; Hartmann, H.; Bansmann, J.; Behm, R.J. CO adsorption energy on planar Au/TiO 2 model catalysts under catalytically relevant conditions. J. Catal. 2007, 252, 171-177. [CrossRef]

98. Bourane, A.; Dulaurent, O.; Bianchi, D. Heats of Adsorption of the Linear CO Species Adsorbed on a $\mathrm{Pt} / \mathrm{Al}_{2} \mathrm{O}_{3}$ Catalyst in the Presence of Coadsorbed Species Using FTIR Spectroscopy. Langmuir 2001, 17, 5496-5502. [CrossRef]

(C) 2018 by the author. Licensee MDPI, Basel, Switzerland. This article is an open access article distributed under the terms and conditions of the Creative Commons Attribution (CC BY) license (http:/ / creativecommons.org/licenses/by/4.0/). 